\title{
MARINE TRANSGRESSION RECORDS IN THE SEPETIBA BAY REGION (RJ-BRAZIL) BY GPR AND GROUND MAGNETIC SURVEY
}

\section{Dione Nunes do Nascimento ${ }^{1}$, Marcelo dos Santos Salomão ${ }^{2}$, Miguel Angelo Mane $^{2}$, Mauro Cesar Geraldes ${ }^{2}$, Ciro Appi ${ }^{2}$ and Maria Virginia Alves Martins ${ }^{2,3}$}

1 Instituto de Estudos do Mar Almirante Paulo Moreira, Praia dos Anjos, Arraial do Cabo/RJ, Rio de Janeiro, Brazil

2 Universidade do Estado do Rio de Janeiro - UERJ, Faculdade de Geologia, Av. São Francisco Xavier, 524, Maracanã, Rio de Janeiro, Brazil

3 Universidade de Aveiro, Departamento de Geociências, GeoBioTec, Campus de Santiago, 3810-193, Aveiro, Portugal

*CORRESPONDING AUTHOR, mauro.geraldes@gmail.com

\section{Received on 14 November 2019 \\ Received in revised form on 13 December 2019 \\ Accepted on 14 December 2019}

Editor: Sergio Bergamaschi, Universidade do Estado do Rio de Janeiro, Brazil

\begin{abstract}
This work aims to identify sedimentary and basal rocks structures in the Sepetiba Bay Basin (Rio de Janeiro State, SE Brazil) located in the western portion of Guanabara Graben formed during the course of Paleocene tectonic activity. Two distinct geophysical tools were used to investigate the geological records by the integration of geological survey and geophysical data: Ground-penetrating radar (GPR) and Ground Magnetic survey. GPR results allowed to interpret and delimit subsurface layers of the basin. It was observed in the analyzed all sections, that the most superficial layers of the radargrams (about 8 meters; with Radar $100 \mathrm{Mhz}$ ) the
\end{abstract}

\section{Introduction}

Coastal regions are boundaries between continents (emerged land) and oceans (submerged lands) in dynamic equilibrium conditions (Wong et al., 2014). These areas are occupied by $2 / 3$ of the Earth's population that is, 7,7 billion people live in coastal areas.

The segments of Sepetiba Bay and the Sepetiba Bay Basin, analyzed in this work, are located in the municipality of Itaguaí, southern Rio de Janeiro State, geographically located in the western part of the Guanabara Graben (Figs. 1-3; Ferrari, 1990; Geraldes et al., 2006; Potratz et al., 2019). The hydrographic network limit is given by the ridges of the Pedra Branca Mountain, starting at Morro de Guaratiba (southeast), following the Serra Geral de Guaratiba, Serra do Rio da Prata, Serra da Pedra Branca, Viegas and Lameirão mountains (Fig. 4). Tracing the tops of the hills and following the ridges, we reach the Macuco and Couto Mountains (local expressions of Serra do Mar). These barriers mark the eastern boundary of the basin, from this

\section{Citation:}

Nascimento, D.N., Salomão, M.S., Mane, M.A., Geraldes, M.C., Alves Martins, M.V., 2019. Marine Progression records in the Sepetiba Bay region (RJ-Brazil) by GPR and Ground Magnetic survey. Journal of Sedimentary Environments, 4 (4): 518-539.

presence of clay and silty sediment layers, related to a calm depositional environment and below $8 \mathrm{~m}$ sandy layers related to more energetic depositional environment were found. These sedimentological changes should be influenced by sea level oscillations and marine transgressions in this area. Magnetic ground survey allowed to identify basement rocks of the Sepetiba Bay Basin and to confirm the event of sea level rise.

Keywords: Coastal area. Sedimentary basin evolution. Past Sea Level Changes. Magnetometry. GPR.

line the rivers to the west drain into Sepetiba Bay (Rocha et al., 2010), and those from the east to Guanabara Bay (Fig. 1).

Studies on the sedimentary evolution of Sepetiba Bay indicate that the present area was already exposed to subaerial processes during the last marine regression, in the Upper Pleistocene (between $\approx 127-20 \mathrm{ka}$; Monroe and Wicander, 2005). Subsequently, the last transgression, in the Late Pleistocene-Holocene drowned this area (Roncarati and Barrocas, 1978; Suguio, 2003; Pinto et al., 2016, 2019; Cunha et al., 2009, 2018).

Combined with effects of sea level change during the Cenozoic, tectonic processes in Serra do Mar, led to the formation of a series of small basins in southeast Brazil (Zalán and Oliveira, 2005). It was then observed that the Sepetiba Bay Basin, inserted in this context, still lacks studies of subsurface structures, which may contribute to a better understanding of its tectonic and sedimentary evolution. 

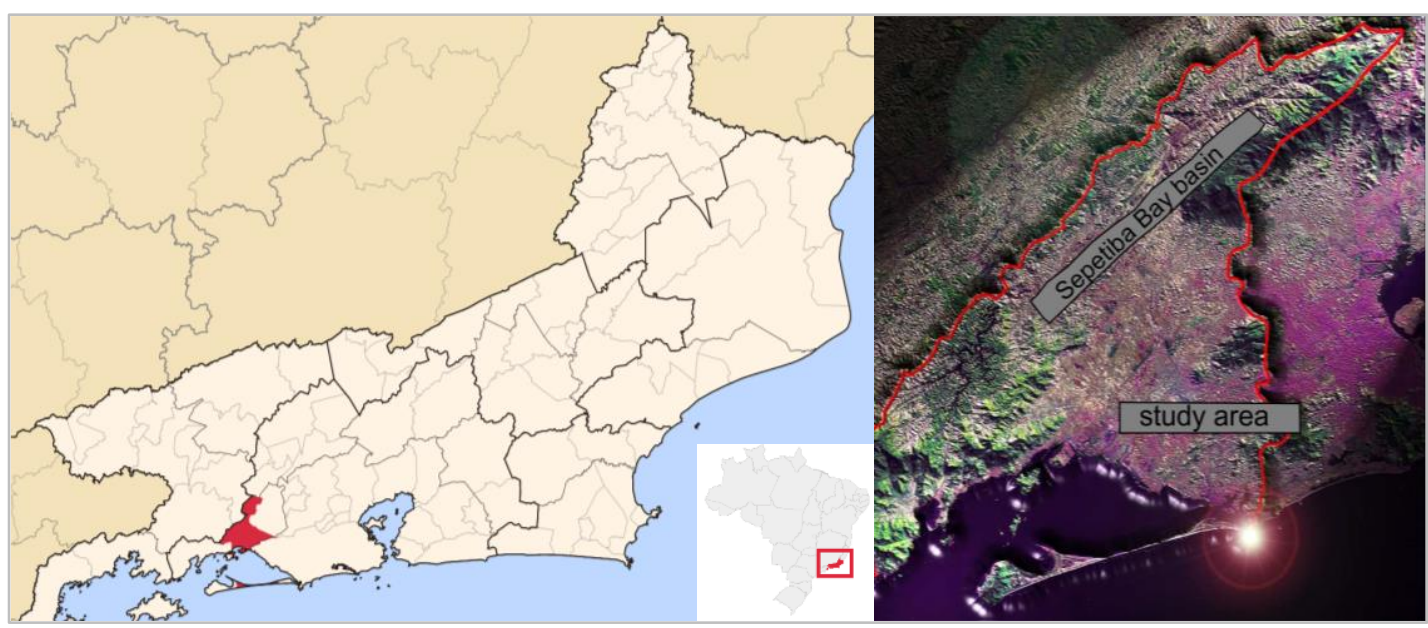

Fig. 01 - Itaguaí Microregion (in red) and location of the Sepetiba Bay Basin with topographic boundaries (Serra do Mazomba on the left and Serra do Couto on the top right, indicated in Fig. 2).

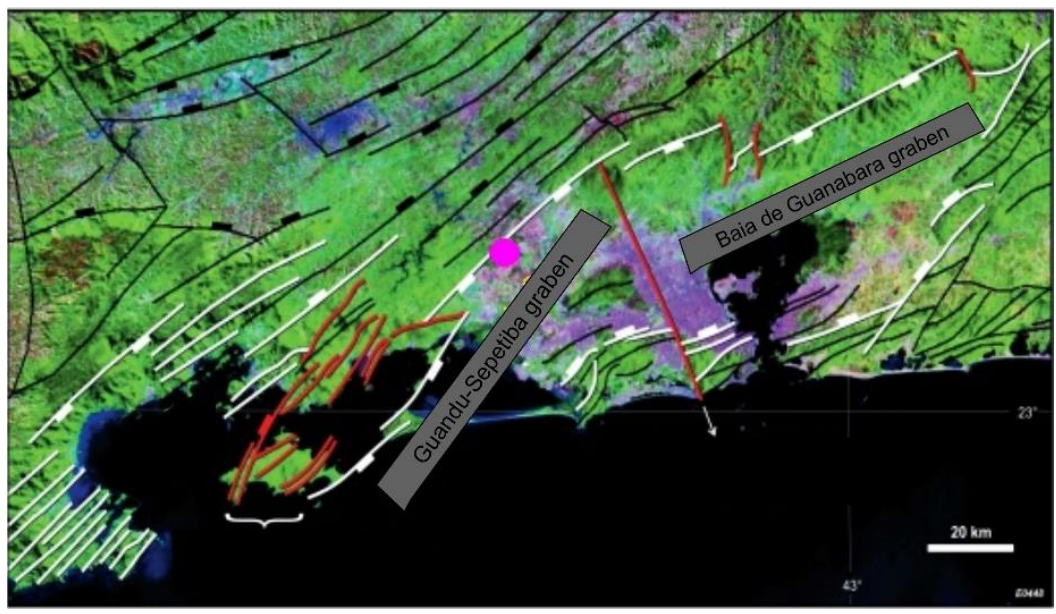

Fig. 2 - Satellite image (TM Landsat7) of the Guandu-Sepetiba Sub-Graben - (SGGS) with the structural interpretation and subdivisions of the Guanabara Graben. Major faults in white. Location of this study area (indicated by a pink circle) (adapted from Zalán and Oliveira, 2005).

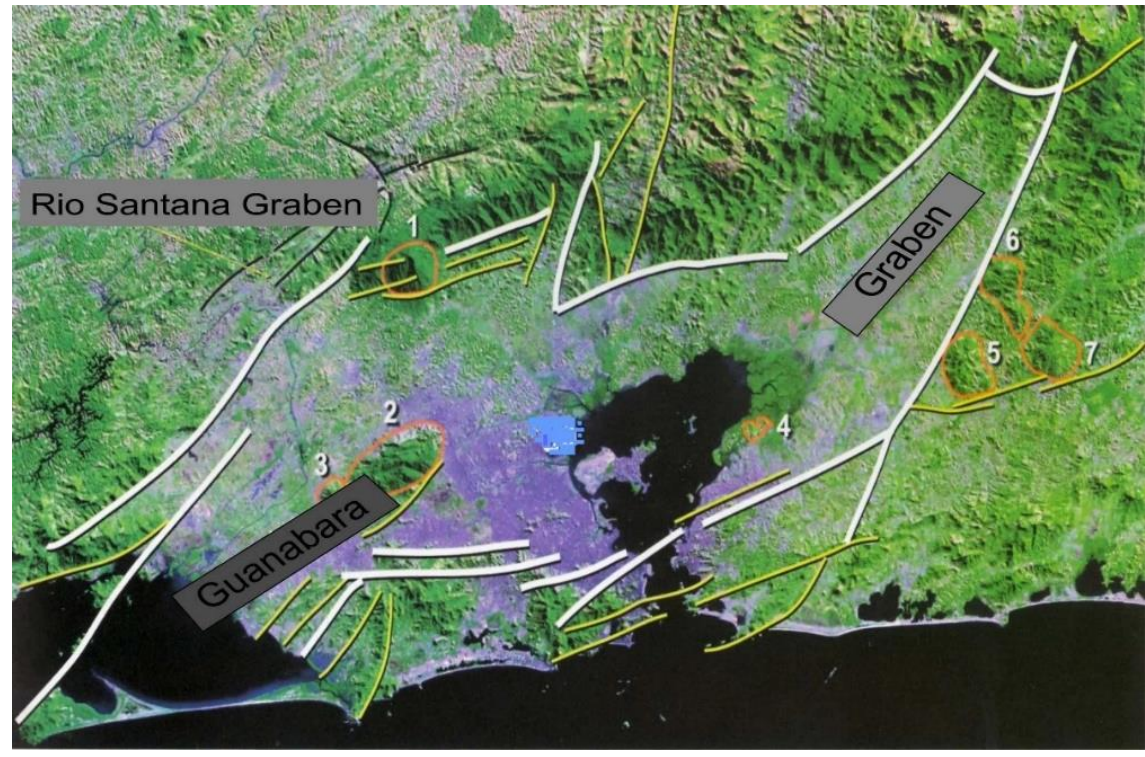

Fig. 3. NASA satellite image of the Guanabara Graben illustrating the alkaline magma events: 1 Tinguá, 2 Mendanha, 3 Marapicu, 4 Itaúna, 5 Tanguá, 6 Soarinho, 7 Rio Bonito. 


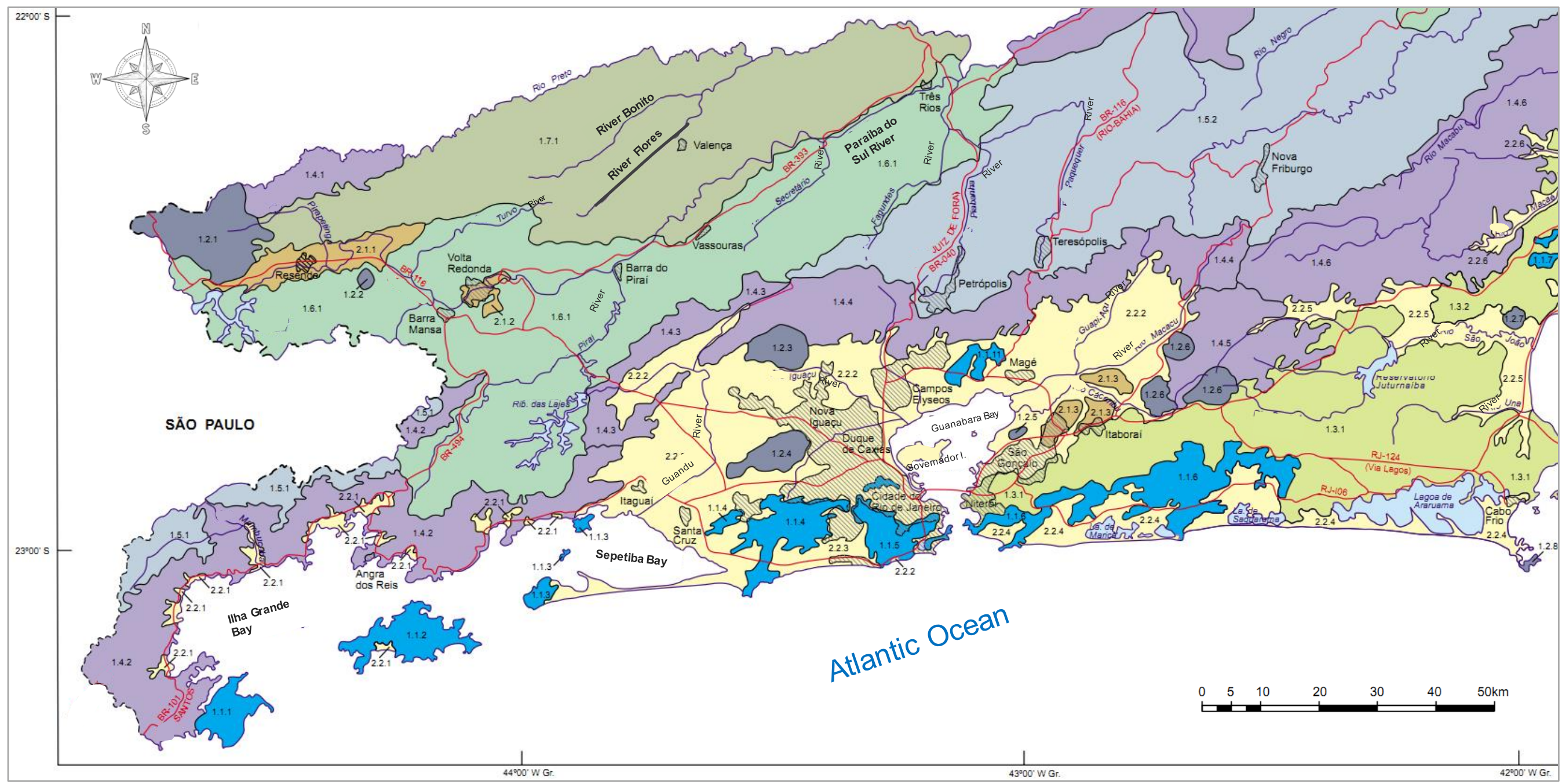

Figure 4. Map of Rio de Janeiro State Geomorphological Units (adapted from Dantas (2000). See the legend on the next page. 
Legend of Figure 4:

\section{1- ATLANTIC OROGENIC BELT OF SOUTHERN BRAZIL MORPHOSTRUCTURAL DOMAINS \\ 1.1 - COASTAL AND INTERIOR MASSIFS}

1.1.1 - Massif of Juatinga

1.1.2 - Massif of llha Grande

1.1.3 - Massif of Marambaia, Jaguanum \& Itacuruçá Islands

1.1.4 - Massif of Pedra Branca

1.1.5 - Massif of Tijuca

1.1.6 - Massif of Região dos Lagos (Lacs Region)

1.1.7 - Massif of Macaé

1.1.8 - Massif of Morro do Coco

1.1.10 - Massif of Bom Jesus de Itabapoana

SERRA DO MAR CLIFFS

- Massif of Suruí

1.1.12- Massif of Conceição de Macabu

\section{2 - INTRUSIVE ALKALINE MASSIFS}

\subsection{1 - Massif of Itatiaia \\ 1.2.2 - Morro Redondo}

1.2.3 - Massif of Tinguá

1.2.4 - Massif of Mendanha

1.2.5 - Massif of Itaúna

1.2.6 - Massif of Tanguá \& Rio Bonito

1.2.7 - Morro de São João

1.2.8 - Cabo Frio island

1.3 - FLATTENED SURFACES IN COASTAL PLAINS

1.3.1 - Flattened region of Região dos Lagos (Lacs Region)

1.3.2 - Flattened surface of Fluminense East Coast

\section{4 - MOUNTAIN ESCARPMENTS}

1.4.1 - Escarpment of Serra da Mantiqueira ESCARPMENT OF SERRA DO MAR

1.4.2 - Escarpment of Bocaína, Mangaratiba \& Mazomba mountains

1.4.3 - Escarpment of Araras \& Paracambi mountains

1.4.4 - Escarpment of Couto \& Órgãos mountains

1.4.5 - Ridge of Santana \& Botija mountains

1.4.6 - Escarpment of Macaé, Macabu \& Imbé mountains

1.4.7 - Reserve Escarpment of Serra do Desengano

1.4.8 - Plateau Escarpment of Varre-Sai

1.4.9 - Escarpment Plateau Reserve of Região Serrana
1.5 - RESIDUAL PLANALTS

1.5.1 - Plateau of Bocaine

1.5.2 - Serra dos Órgãos reverse plateau

1.5.3 - Varre-Sai plateau

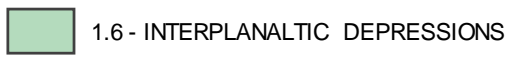

1.6.1 - Depression of the middle valley of Paraíba do Sul River

1.6.2 - Depression of the Negro River valley

1.6.3 - Depression of the Pomba River valley

1.7 - INTERPLANA

1.7.1 - Depression with aligned mountains of the middle valley of Paraíba do Sul River

1.7.2 - Depression with North-Northwest Fluminense aligned mountains

2- CENOZOTIC SEDIMENTARY BASINS

MORPHOSTRUCTURAL DOMAINS

2.3 - SEDIMENTARY AND CENOZOIC BASIN FLAKES

2.1.1 - Resende basin

2.1.2 - Volta Redonda basin

2.1.3 - Macacu basin

2.1.4 - Quissamã flake

2.1.5 - São Francisco de Itabapoan flake

NEOCENOZIC AGRADATION SURFACES

2.2 - FLUVIOUS MARINE PLANS (Lowlands )

2.2.1 - Lowlands of Ilha Gande Bay

2.2.2 - Guanabara Bay, Sepetiba and Marambaia Lowlands

2.2.3 - Lowlands of Jacarepaguá

2.2.4 - Lowlands of the Lakes Region

2.2.5 - Lowlands of São João River

2.2.6 - Macaé River Lowland

2.2.7 - Macabu River Lowland

2.2.8 - Imbé River Lowland

2.2.9 - Lowlands of Camper

2.2.10 - Itabapoana River Lowland

2.3 - COASTAL PLAINS

2.3.1 - Sandy ridges of Jurubatiba

2.3.2 - Sandy ridges of Paraíba do Sul River

Figure 4. (cont.) Map of Rio de Janeiro State Geomorphological Units (adapted from Dantas (2000).

The present study aims: (i) to investigate subsurface sedimentary layers in the continental part of Sepetiba Bay Basin using the Ground Penetrating Radar (GPR) technique and; (ii) to identify magnetic anomalies using the ground Magnetometer (iii) to characterize the geological evolution of the Sepetiba Bay Basin. Thus, this investigation intends to delimit depositional layers, their structures and geological characteristics, as well as to analyze basement rock structures of this region.

\section{Study area}

\subsection{Implementation of the Southeast Brazilian Cenozoic Rift System}

During part of the Cenozoic (58 - 20 Ma the continental crust rifted into several linear areas forming parallel shoreline small basins known as Southeastern Cenozoic Rift Systems (SRCSB) (Zalán and Oliveira, 2005).

Based on structural and geomorphology features, four large fragments were defined: Paraíba do Sul, Coastal, Ribeira and Marítimo. Figure 5 from Zalán and Oliveira (2005) illustrates the distribution of these tectono-structural terranes. As result of this event, gravitational collapse occurred at Paraty (further south of the Rio de Janeiro State) and Guandu-Sepetiba sub-grabens, where this study area is located (Fig. 3).

According to Almeida et al. (1981), the dynamics of tectonic events in normal and juxtaposed blocks, installed on the reactivating continental margins, related to the expansion of the ocean floor, lasted until the beginning of the Neogene. At this stage, the alkaline rocks intruded in the reactivated crustal faults. Alkaline magmatism is represented in the study area by Tinguá and Mendanha and the Marapicu massif, as well as by numerous dikes (Ferrari, 2001). The tectonic origin of these alkaline rocks is not yet clear and they have been related to thermal anomaly. In Fig. 5, it is possible to locate the alkaline magmatism events within the Guanabara graben.

Evidence of reactivation has been described for many of the major shear zones and regional faults of southeastern Brazil (Ferrari, 2001). This evolution started in the Mesozoic and was possibly interrupted by the cessation of the magmatic pulses that originated the basic intrusive dikes (Mizusaki et al., 2002). This lithological context formed the 
basement for the deposition of various sedimentary rock packages in Sepetiba Bay Basin, as well as in other basins (Gallagher and Brown, 1999).

Neogene and Quaternary sediments are scattered in the low areas and around the elevations composed by the Proterozoic rocks, forming the Baixada de Sepetiba and the Restinga da Marambaia sedimentary rocks. The granodiorites that make up much of the Tinguá Massif
RESEARCH PAPER

country rocks also occur in small stretches in the Serra do Couto and in the Mendanha and Pedra Branca Massifs (Zalán and Oliveira, 2005).

Disseminated in various lithologies are granites, classified as being of post-orogenetic origin (without structural deformation) and responsible for the formation of isolated hills, part of the islands and much of the Pedra Branca Massif (Heilbron and Machado, 2003).

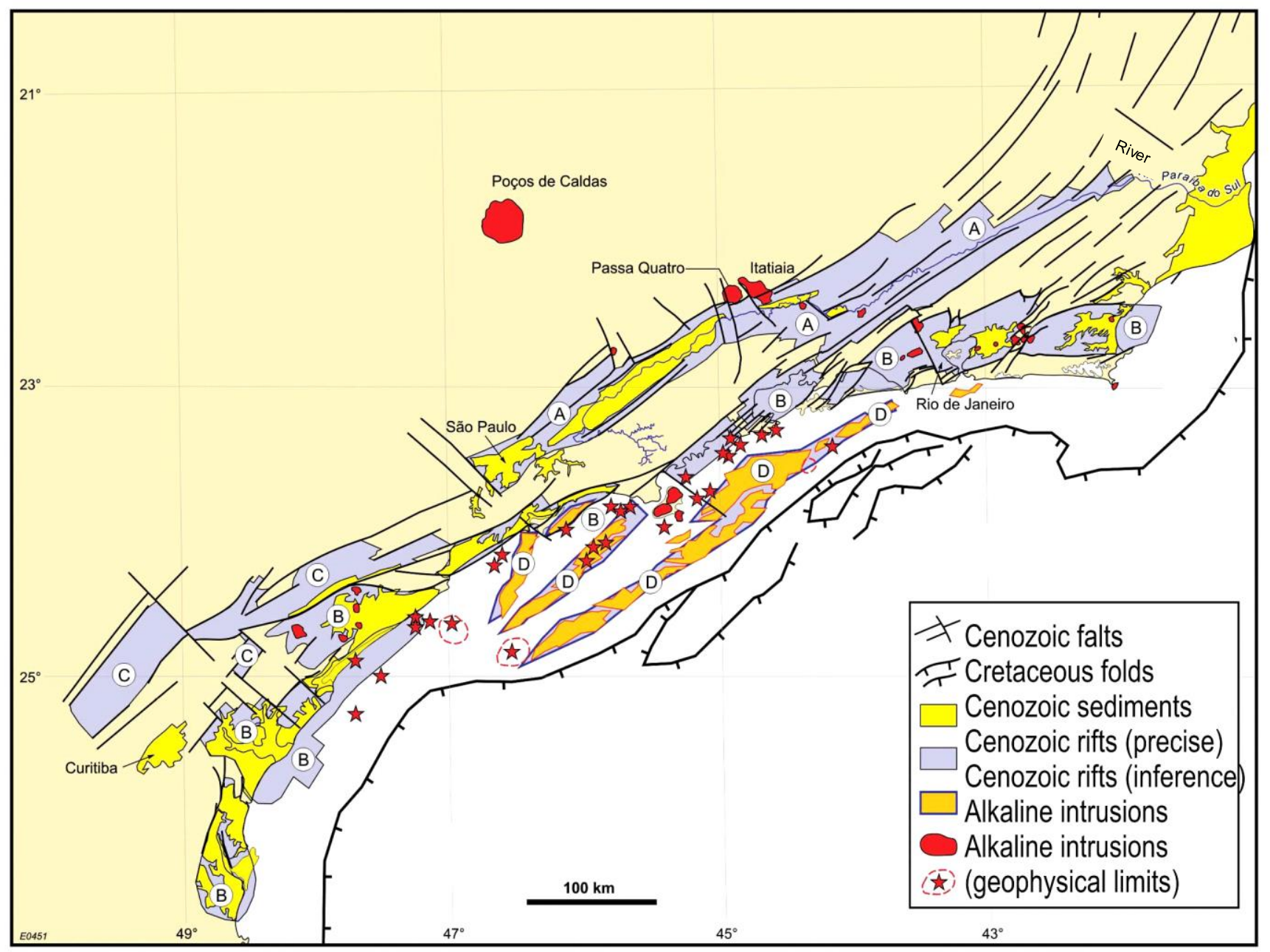

Fig. 5 - Distribution map of the four Southeastern Cenozoic Rift Systems terranes formed during rifting process: (A) Paraíba do Sul, (B) Coastal, (C) Ribeira, and (D) Maritime. (Zalán and Oliveira, 2005).

\subsection{Sea level change}

Large sea level oscillations occurred in the Quaternary period, playing a major role in the evolution of the shorelines, exposing most of the present continental shelves or partially or completely covering the present coastal plains (Murray-Wallace and Woodroffe, 2014). During this period the main factor that caused changes in ocean levels was the growth and disintegration of continental glaciers, which were responsible for global variations in ocean level (Kominz, 2001).

On the other hand, local sea level changes can be juxtaposed with eustatic phenomena by increasing or decreasing the global effects of rising or falling sea levels. Thus, the resultant of this conjugation between global and regional phenomena determine the Relative Sea Level behavior in a given region (Khan et al., 2015).

Local phenomena are controlled by tectonic dynamic, oceanographic or meteorological phenomena, or by high sedimentation rates (Khan et al., 2015). The response of sea level rise on the shoreline is immediate, resulting in drowning and erosion of coastal plain deposits. In Brazil, several studies point to a behavior of sea level rise in the last century (Pirazolli, 1986; Harari and Camargo, 1993), which is compatible with the erosive trend observed in many sectors of the coastline, such as the coast of northeastern 
cliffs and some sandy beaches in Pernambuco, Bahia and Rio de Janeiro (Bird, 1987; Muehe, 1994; Paula and Geraldes, 2005).

In Brazil, several works suggested that in the last 10,000 years sea level changed in most of the Brazilian east coast, showing a transgressive maximum of 4 meters above the current level at about 5,100 years BP (Fig. 6; e.g. Martin et al., 1979a; Suguio et al., 1985; Angulo and Lessa, 1997; Angulo et al. 2006; Hein et al. 2014; Jesus et al., 2017; Cooper et al., 2018). Since than according to some authors should have occurred small oscillations (Martin and Suguio, 1992). Although details of relative Holocene sea level variability along the coast of Brazil have been the target of many studies, Angulo and Lessa (1997) and Angulo et al. (2006) believe that some identified oscillations are due to errors in determining age.

In the late 1970 s and early 1980s, a number of studies were conducted on the Brazilian coastal Quaternary, along the Bahia, São Paulo and South Rio de Janeiro coast and on the coastal plains along the mouth of large rivers (Bittencourt et al., 1979; Bittencourt et al., 1982; Dominguez et al., 1981, 1982; Dominguez, 1982; Flexor et al., 1979;
RESEARCH PAPER

Martin et al., 1979a; Suguio and Martin, 1982). These investigations showed two sets of sandy terraces, with distinct characteristics, formed during the regressions that followed the last two transgressive phases.

The first set of terraces, the top of which reaches 8 to 10 $\mathrm{m}$ in size, belongs to the Pleistocene, aged around 120,000 years BP and is associated with the transgression process, the maximum of which occurred around this time (Bittencourt et al. 1982). The deposits were probably formed in the final phase of the transgressive event and subsequent regression.

The second set of marine terraces is generally located on the outside of the older terraces. Its top is between 4 and 5 $\mathrm{m}$ above sea level inland, falling to less than $1 \mathrm{~m}$ in the outermost parts, which is a strong evidence that its formation occurred during a regressive phase. Samples dated by the radiocarbon method allowed to locate the terraces in the Holocene associated with the last Transgression (Bittencourt et al. 1982). Sea level changes left marked records in Brazilian coastal areas (e.g. (e.g. Angulo and Lessa 1997; Angulo et al. 2006, 2008, 2016; Hein et al. 2014; Jesus et al. 2017; Cooper et al. 2018).

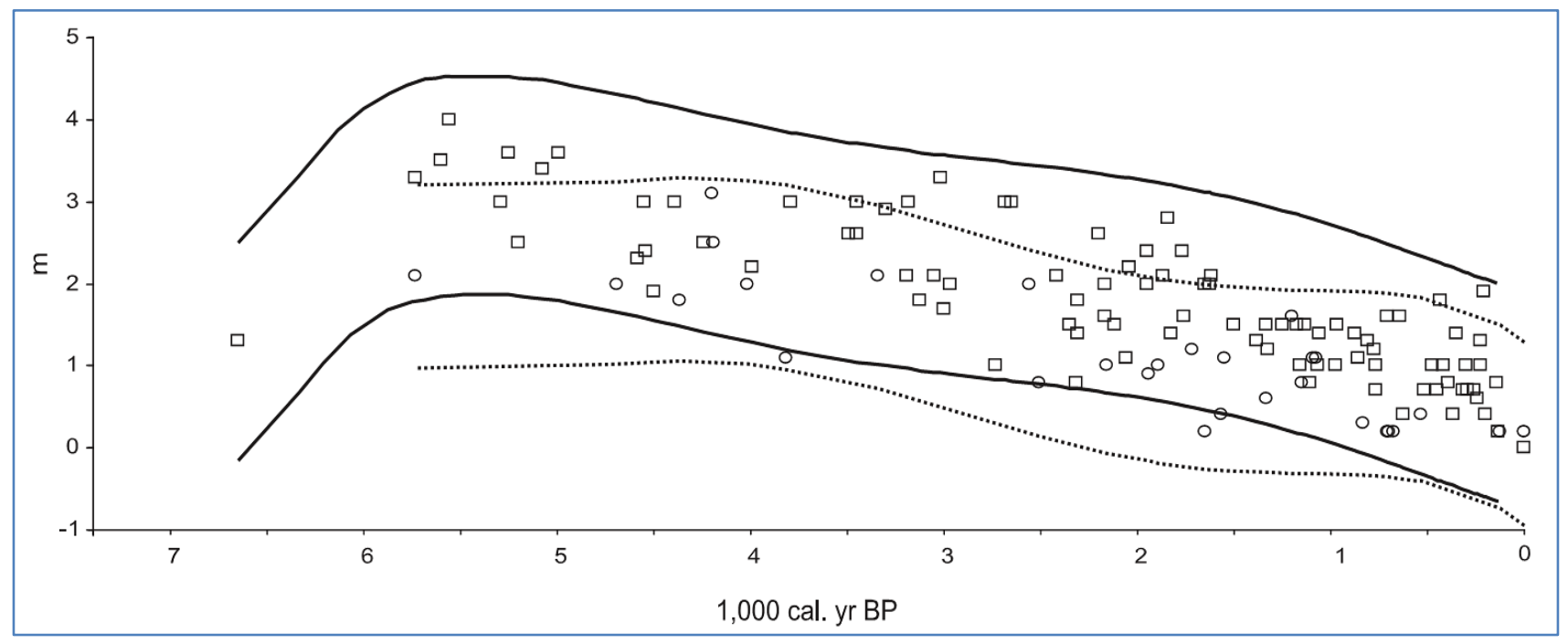

Fig.. 6. sea level changes over the last 7,000 years for the Brazilian coast north $28^{\circ}$ (solid line and squares) and south of $28^{\circ}$ ( $d$ ashed line and circles), based on vermetid samples and with outliers removed (Angulo et al., 2006).

\section{Materials and methods}

\subsection{GPR data acquisition}

The GPR equipment used in this work was the RAMAC, manufactured by the Swedish company MALA Geoscience, applying the reflection or common offset arrangement. Antennas with frequencies of $100 \mathrm{MHz}$ and $50 \mathrm{MHz}$ are both unshielded. Along with the antennas, a central control unit (UCC) and a notebook were used to execute the acquisition program data. The connections between the Transmitter and Receiver units and the UCC were made through fiber optic cables, as metallic wires could produce interference. Four sections were performed and all were made near the border of the Itaguaí basin and the outcropping basement (Fig. 7).

Data collection was performed in two days: On May 14, 2013, the acquisition was made on the $\mathrm{AB}$ and EF profiles with the $100 \mathrm{MHz}$ antenna, covering approximately 6,000 meters in total length (Fig. 7). The second acquisition stage took place on June 25, 2013 in the Base profile, using 100 and $50 \mathrm{MHz}$ antennas, and in the Farm profile, using only the antenna of $50 \mathrm{MHz}$.

Data with $50 \mathrm{MHz}$ antenna were acquired with distance between reading points of 1 -meter, distance between 
antennas of 03 meters, and sampling interval of $0.417 n \mathrm{~ns}$. For the $100 \mathrm{MHz}$ antenna was also used the distance of 01 meters between the reading points, but the distance between the antennas was 01 meter and the sampling interval of 1.419ns To determine the propagation velocity of electromagnetic waves, different
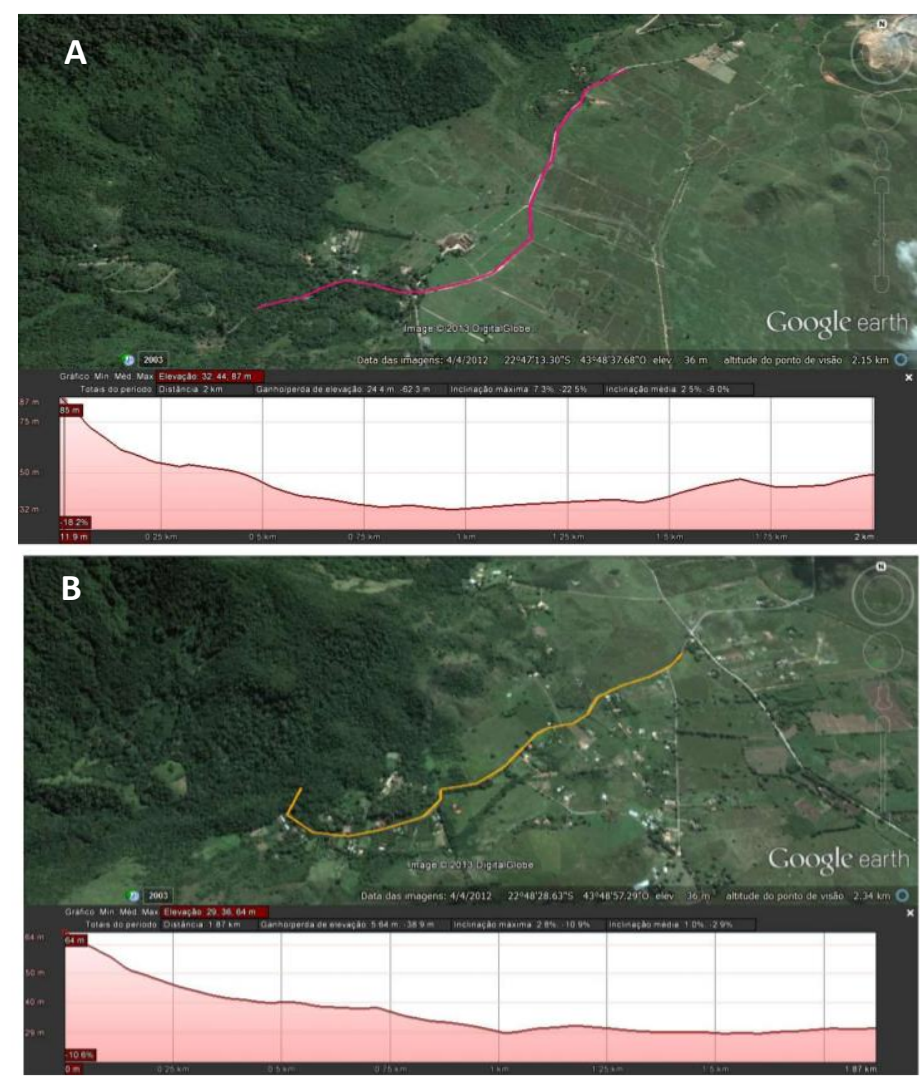

velocities were used between $0.017 \mathrm{~m} / \mathrm{ns}$ and $0.045 \mathrm{~m} / \mathrm{ns}$ with an increment of $0.01 \mathrm{~m} / \mathrm{ns}$ for data migration. The velocity of $0.045 \mathrm{~m} / \mathrm{ns}$ was the one that best attenuated the diffraction effects of the waves, eliminating the hyperboles without attenuating the reflector dive.
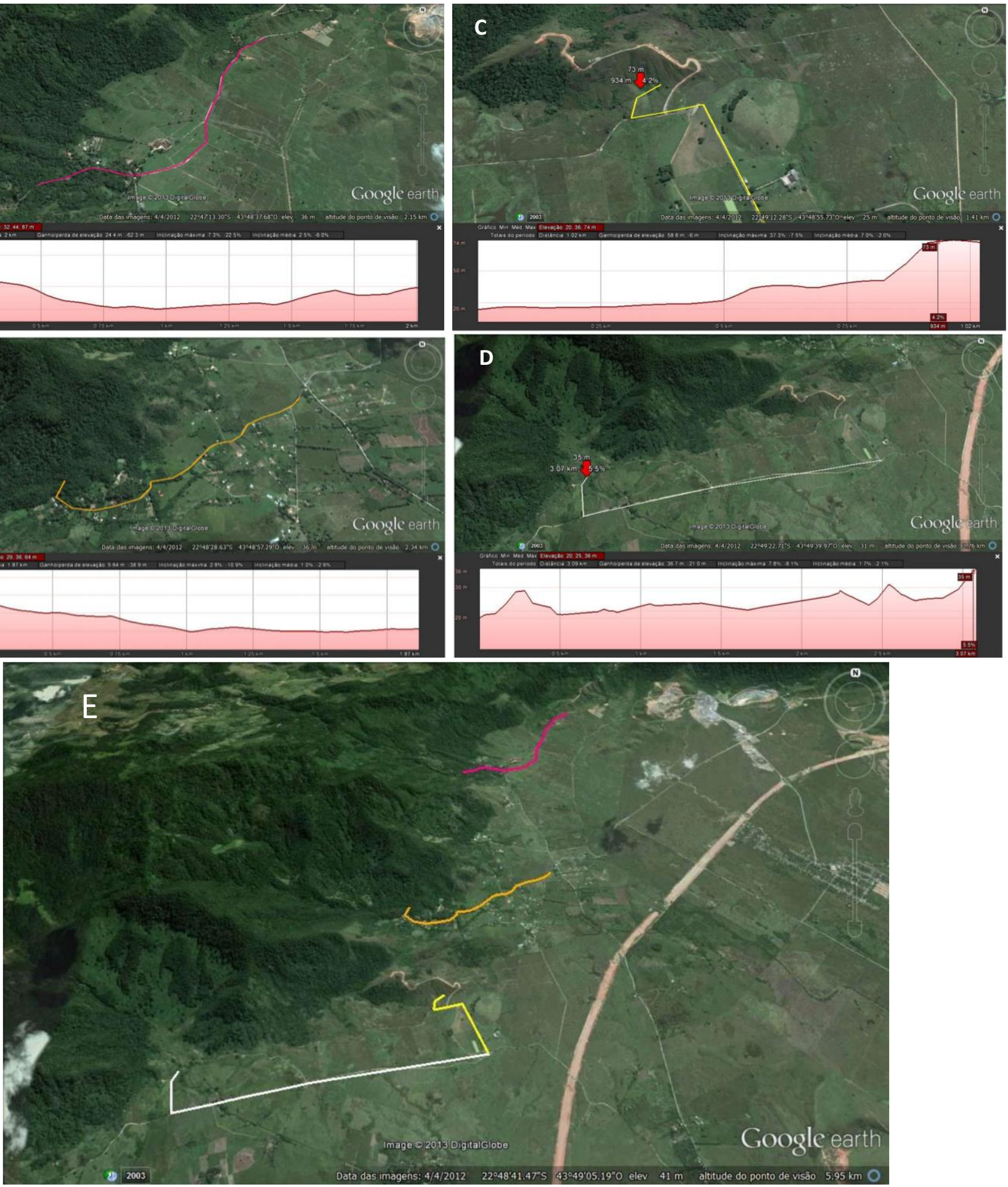

Fig. 7 - (A-D) Satellite image showing the location of profiles and its elevation profile (Google Earth 2013). E. Satellite image showing the location of the profiles. EF profile in white, Farm profile in yellow, Base profile in orange and AB profile in pink. (Google Earth, 2013). 
Data processing consists of a set of signal processing techniques applied to digitized data, with the purpose of making them suitable for visual interpretation, producing clearer sections and better temporal resolution of the subsurface layers. The processing data can be basic or advanced and goes through the following steps: data editing, time-zero corrections, dewow filtering, automatic gain control (AGC) applications, migration, bandpass filtering, and time/depth conversion. The program used in processing data was REFLEX Win, version 4.5.

Time-zero correction aims to adjust the initial recording time to the first reflector found so that the first reflection in the different strokes is horizontally aligned. Dewow filtering consists of removing low frequencies related to induction phenomena or limitations of the dynamic range of the instrument.

Subsequently, an AGC gain is added to the data, as this type of gain is appropriate when only one stratigraphic and geometric study is desired since this gain equalizes the amplitudes.

In practice, when propagated in the geological environment, absorption and dispersion effects attenuate the GPR pulse. These effects manifest themselves on the radargram mainly as loss of depth resolution. As a result, the amplitude spectrum decreases and a center frequency shift occurs towards the lower frequency components, leading to spectrum unbalance. GPR pulse attenuation is more pronounced in high frequency components. Therefore, spectral balancing corrects the effects of attenuation selectively across frequency bands.

Migration process is an important step in GPR data processing as it allows building a more accurate image of the subsurface. However, in general, this step adds noise and then different speed tests should be performed to obtain the best possible result. Bandpass filtering is a spatial filter and is intended to emphasize slanted events (High Pass) and to emphasize horizontally stratified events (Low Pass), thereby enhancing radar view. Finally, the time-depth conversion aims to transform the plotted radargram as a function of time to depth, in order to facilitate the interpretation of the observed structures.

\subsection{Ground Magnetic Survey}

The ground magnetic survey profiles were performed near the Mazomba mountain cliff, in the inner part of the Sepetiba Bay basin, in the municipality of Itaguai/RJ. The magnetic survey was carried out in three field days, two profiles on $06 / 29 / 2013$, one profile on $06 / 30 / 2013$ (the longest, over 2,500 meters in length) and the last profile on the $07 / 07 / 2013$, covering about 6,500 meters in total. The device used was the GSM-19 Overhouser Magnetometer.

The measurements of the total geomagnetic field component were made with two magnetometers, whose sensitivity is $0.01 \mathrm{nT}(10-10$ Tesla), one moving and the other
RESEARCH PAPER

serving as the base for diurnal correction. A total of 751 measurements were obtained across all 04 profiles (Fig. 7). Removal of time variations of the geomagnetic field and monitoring of daytime variation of the geomagnetic field was performed on a fixed base where a reading was taken every 10 seconds in survey lines. The time variation of the field was removed by subtracting the diurnal field variations from a reference field. For the diurnal base on $06 / 29 / 2013$, the reference field value was $23254.82 \mathrm{nT}$, on $06 / 30 / 2013$, the value was $23296.35 \mathrm{nT}$, and on $07 / 07 / 2013$ the value was $23295.55 \mathrm{nT}$, corresponding to the first reading at the diurnal base that coincided with the beginning of the measurements along the profile.

The processing of ground magnetic data followed an execution schedule according to Oasis Montaj 7.1 and GMSys both from Geosoft GMSys program. In the generation of grids, the MAGMAP-step filtering, Map Tools, Grid and Image and Coordinates menus were used.

In order to investigate the subsurface sedimentary package layers located in the continental part of the Sepetiba Bay basin, the qualitative interpretation method was used in this research. This method aims to determine information about structures and underground stratigraphy. To corroborate the interpretation, we used information from a borehole conducted by the company Tecnosolo Ltda., having a distance of about $1 \mathrm{~km}$ from the profiles, thus helping in the geological correlation.

\section{Results}

\subsection{GPR - Ground-Penetrating Radar}

Results of the survey profiles in the study area were included in supplementary material (SM) (Appendix 1: SMFigs. 1-6). Through stratigraphy or layer sequence analysis of GPR sections, 03 basic types of reflection patterns were identified:

- Incoherent or chaotic: This pattern is associated with unconsolidated or disaggregated materials.

- Laminate or parallel plane: pattern associated with continuous horizontal reflectors, related to horizontal or sub-horizontal bedrock structures characteristic of sedimentary rocks (Fig. 8).

\begin{tabular}{ccc}
\hline \multicolumn{1}{c}{ Description } & Litology \\
\hline $\begin{array}{l}\text { Continuous reflectors, } \\
\text { locally irregular }\end{array}$ & $\begin{array}{l}\text { Fine sandstones } \\
\text { with clays }\end{array}$ \\
\hline $\begin{array}{l}\text { ondulated reflectors, } \\
\text { continuous and crossed, }\end{array}$ & $\begin{array}{l}\text { Coarse-grained sandstones } \\
\text { with local clays intercalations }\end{array}$ \\
\hline
\end{tabular}

Fig. 8. Reflector patterns found in radargrams.

- Hyperboles and diffractions and lateral discontinuities: characteristic pattern of geological discontinuities (faults, fractures) or buried objects. 
In the Profile AB1 (100 Mhz) presented in Fig. 9A, two types of reflectors were delimited. A parallel plane from the top of the radargram to a depth of 08 meters and another wavy to chaotic below 08 meters deep. Through the probing profile, such reflectors can be correlated with the different lithologies: yellow reflectors are clay to silt layers, and red reflectors represents sandy sediments.

Profile AB2 (100 Mhz) (Fig. 9B) is the continuation of the previous one and, therefore, the same reflector types of the previous profile were identified and delimited. A parallel plane from the top of the radargram to a depth of 08 meters and another undulating but less chaotic below a depth of 08 meters. The same interpretation of the $\mathrm{AB} 1$ profile can be considered in this case, that is, the yellow reflectors are silt layers, and the red reflectors are related to sandy sediments.

The Base Profile, obtained with a $50 \mathrm{MHz}$ antenna (Fig. 9C), presented a predominantly chaotic to wavy reflector pattern from 02 meters deep. Plane-parallel reflectors were also observed up to 02 meters deep. Correlating these reflectors with the probing profile can be said that in yellow are clay and silt layers, and in red are also sandy sediments

The Base profile obtained with a $100 \mathrm{MHz}$ antenna (Fig. 9D), presented a predominantly wavy reflector pattern from 06 meters deep. Plane-parallel reflectors were also observed above 06 meters deep. Correlating these reflectors with the probing profile can be said that in yellow are clay and silt layers, and in red, sediment layers such as gravel and sand.

The EF profile 9 (Fig. 9E), with $100 \mathrm{MHz}$ antenna, presented a general pattern of predominantly flat parallel and less chaotic reflectors up to 11 meters deep. Undulating reflectors are observed below 11 meters deep. The reflectors in yellow are clay layers, and in red, sediment layers such as gravel and sand.

Sediment layers such as gravel and sand in the farm profile, with a $50 \mathrm{MHz}$ antenna (Fig. 9F), presented a pattern of both flat-parallel and wavy to chaotic reflectors. It is observed in detail to the left of the profile the existence of hyperboles suggesting the presence of buried tubes. Correlating the other reflectors with the probing profile it can be said that in yellow are clay and silt layers, up to about 6 meters deep, and in red, sediment layers such as gravel and sand.

\subsection{Results of Ground Magnetic Survey}

The magnetic "transparency" of the sediments in the Sepetiba Bay Basin allows associating the magnetic anomalies with the basement geometry. Magnetic anomalies result from the quantity and spatial distribution of ferrimagnetic minerals in rocks, such as magnetite, hematite and pyrrhotite, that are strongly magnetized when subjected to the external magnetic field. Therefore, the analysis of the results obtained in this work took into account the distribution of survey points, which, due to access restrictions, is irregular in some profiles. After correction of the magnetic field, the corrected magnetic field, analytical
RESEARCH PAPER

signal and first derivative maps were generated for each section. At this stage, the Base, Farm and EF profiles were processed and later modeled.

\subsection{Geological modeling of profiles}

The modeling performed was made through the corrected magnetic field maps of each profile, being loaded in Geosoft GMSys menu. The magnitude used was 23,000 $\mathrm{nT}$ and the declination of -23 degrees. According to the literature, the rock bodies due to the process of generation acquire the magnetic susceptibility and geological evolution of the rock varies according to the grain size, temperature, and may be more or less intense influencing the extraction of information from the rock on magnetic maps.

A rocky body more magnetic than the surrounding rock emits a high intensity anomaly on the map. In addition, the depth of the body influences the intensity of the magnetic signal (Dobrin and Savit, 1988). Based on these statements, the modeling was performed through an intuitive process, adjusting the observed and calculated curves, bringing them as close as possible and creating rock layers generating the models.

In the modeling of the profiles are presented 03 types of rocks in addition to a layer of surface sediment. In Base (Fig. $10 \mathrm{~A}$ ) and EF profiles (Fig. 10B), strong anomalies were observed at the beginning and end of the sections, suggesting the presence of intrusive dikes along them. The Farm profile (Fig. 11) did not present large magnetic anomalies.

\section{Discussion}

Sea level oscillations cause disturbances in the equilibrium profile of the coastal zone (Bruun, 1962) Aagaard and Sørensen, 2012). The natural tendency is to return to equilibrium by migrating this profile along this transitional area. In general, coastal barriers are related to transgressive sea level (Dominguez et al., 1982; Hein et al., 2014). On the other hand, marine sandy spits are formed during coastal progradation, related to rivers sediment supply or relative to sea level drop (Barusseau et al., 1996; Certain et al., 2005a).

Several sections along the coast of Rio de Janeiro State have formations that testify the occurrence of sea level oscillations (Suguio et al., 1985), namely in Sepetiba region, such as: the Marambaia sand spit; transverse sands agglomeration along the southwest bank of the Guandu river formed by coastal drift; the system of extensive transgressive barriers between Angra dos Reis and Itaguai that evolved from the drowning of coastal dunes and sandy beaches.

Note that in the $50 \mathrm{MHz}$ Antenna Base profile data, the chaotic layers are shallower from 4 meters deep and, in the Farm profile data, the progradant features detected with northward reflector direction, suggest an association with a progradation event, possibly during the Holocene (Fig. 12). 
Journal of Sedimentary Environments

Published by Universidade do Estado do Rio de Janeiro

4 (4): 518-539. October-December, 2019
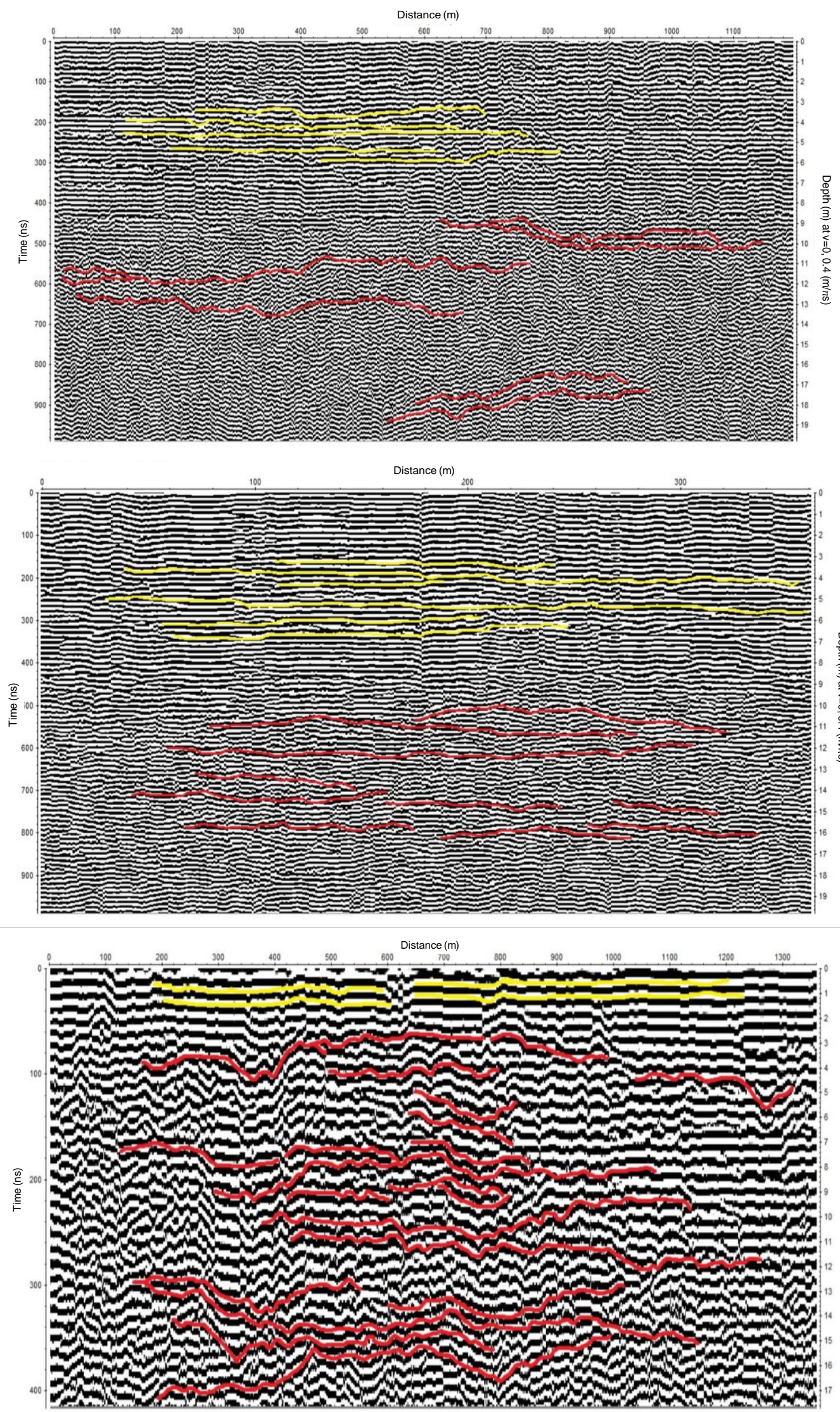

Figure 9 - Interpreted radargrams of the: A. AB1 profile (Radar $100 \mathrm{Mhz})$. B. AB2 profile (Radar $100 \mathrm{Mhz}$ ). C. B) Base profile (Radar $50 \mathrm{Mhz}$ ). Yellow lines (flat-parallel lamination) and red lines (wavy to chaotic stratifications). 

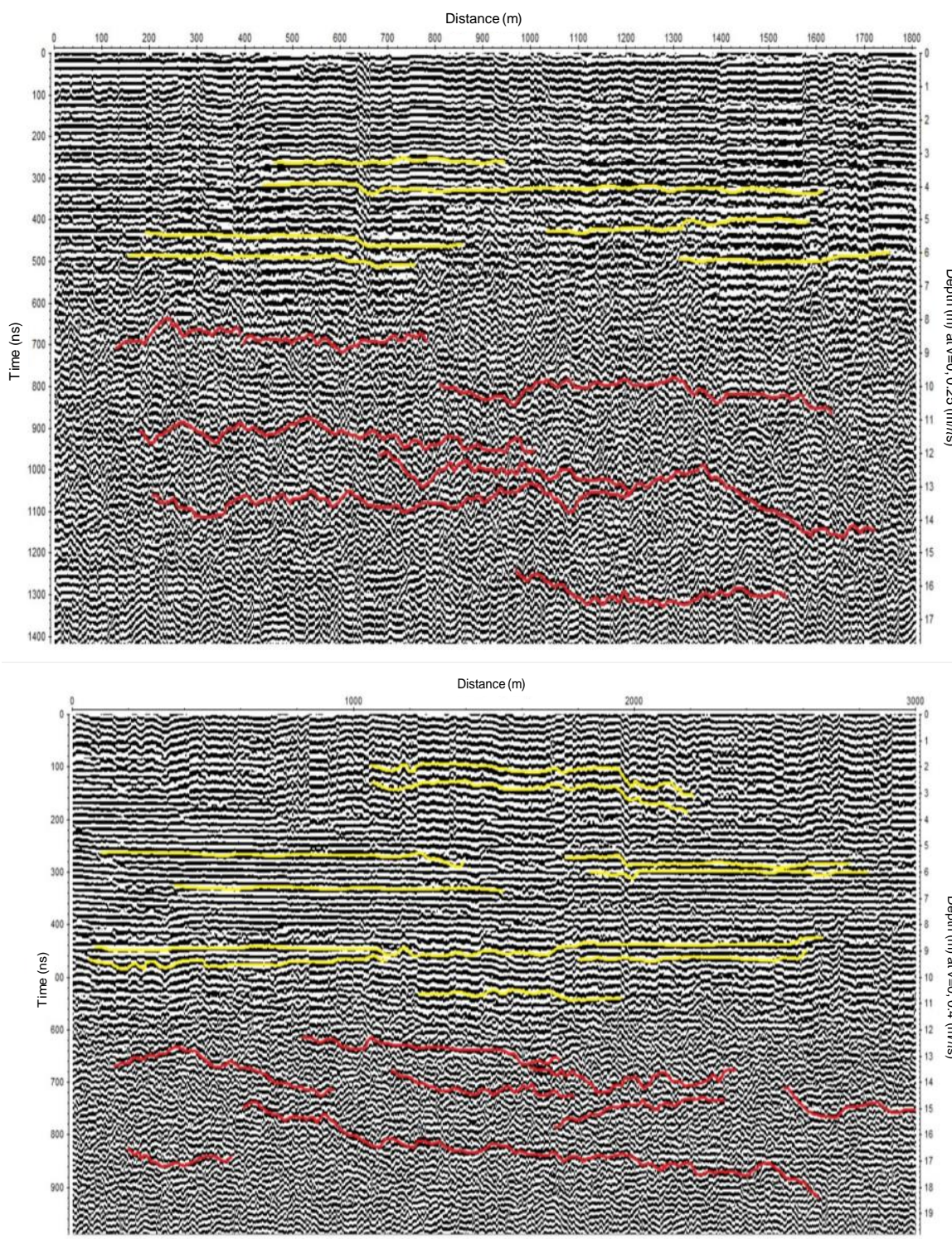

Distance (m)

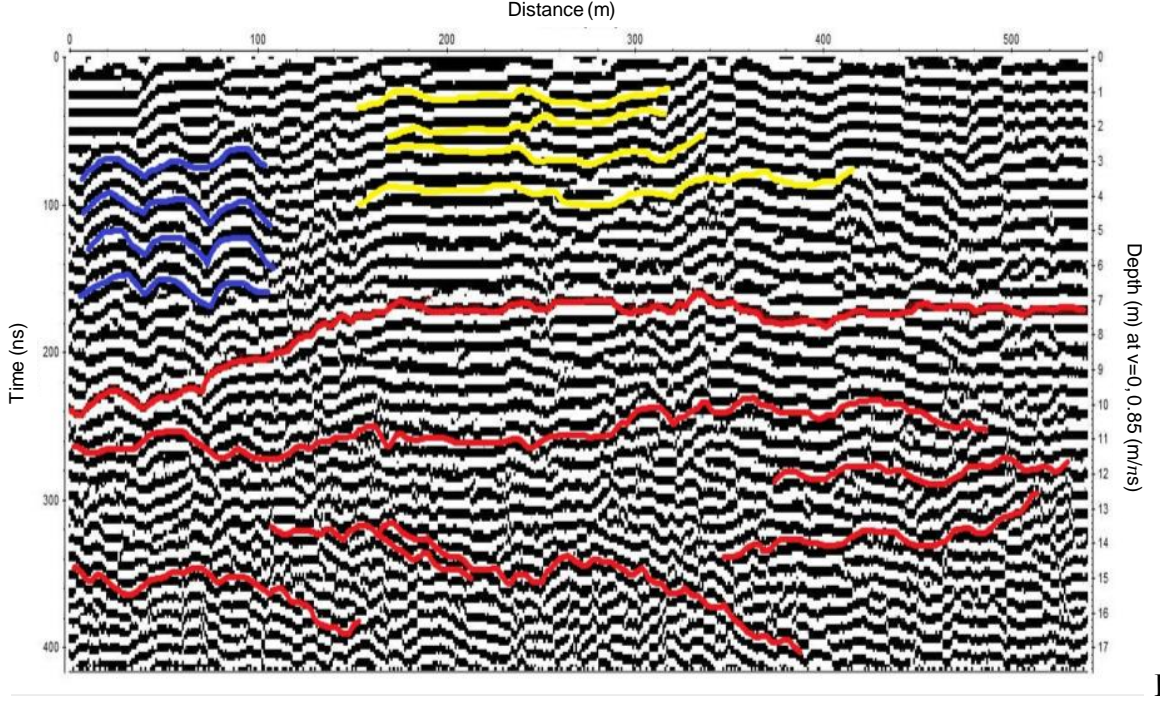

Figure 9 (cont.) Interpreted radargrams of the: D. Base Profile (Radar 100 Mhz). E. EF (Radar 100 Mhz). F. Farm Profile (Radar 50 Mhz). Yellow lines (flat-parallel lamination) and red lines (wavy to chaotic stratifications). Yellow lines (flat-parallel lamination), red lines (wavy to chaotic stratifications) and blue lines show likely buried tubes. 

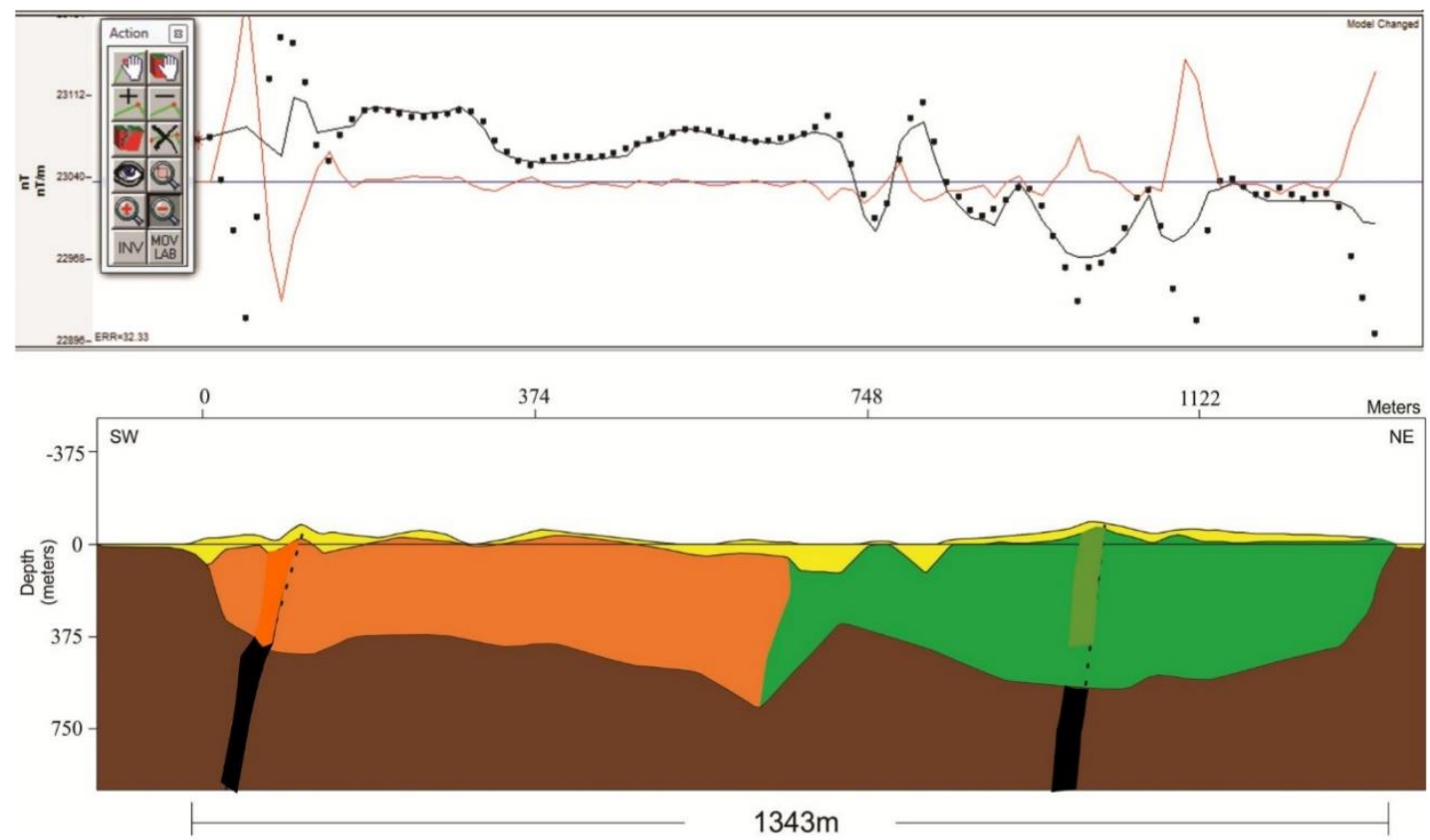

$1343 \mathrm{~m}$
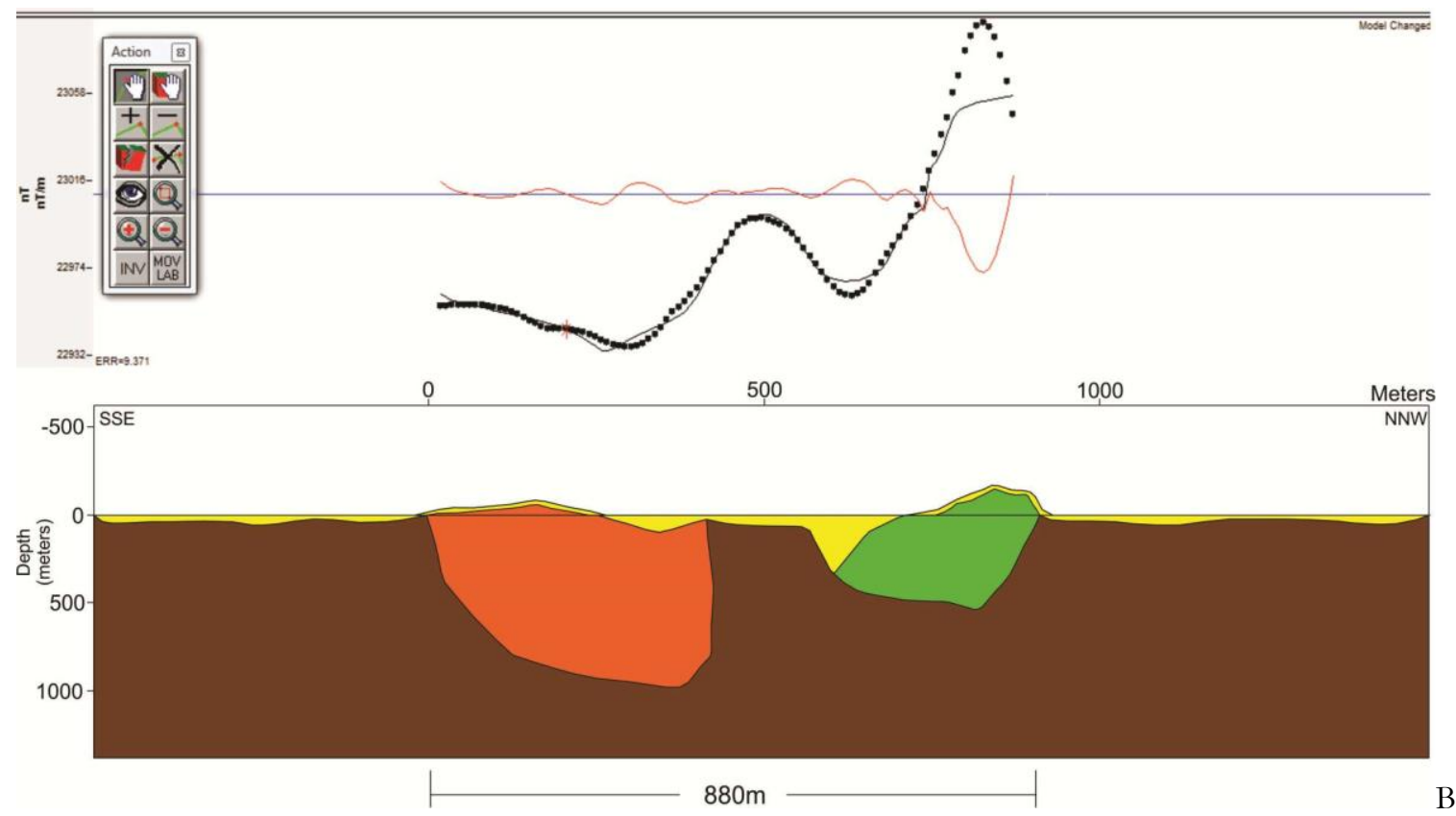

Figure 10 - Geological modeling produced with Geosoft GMSys program of the: A. Base profile and B. Farm profile. 


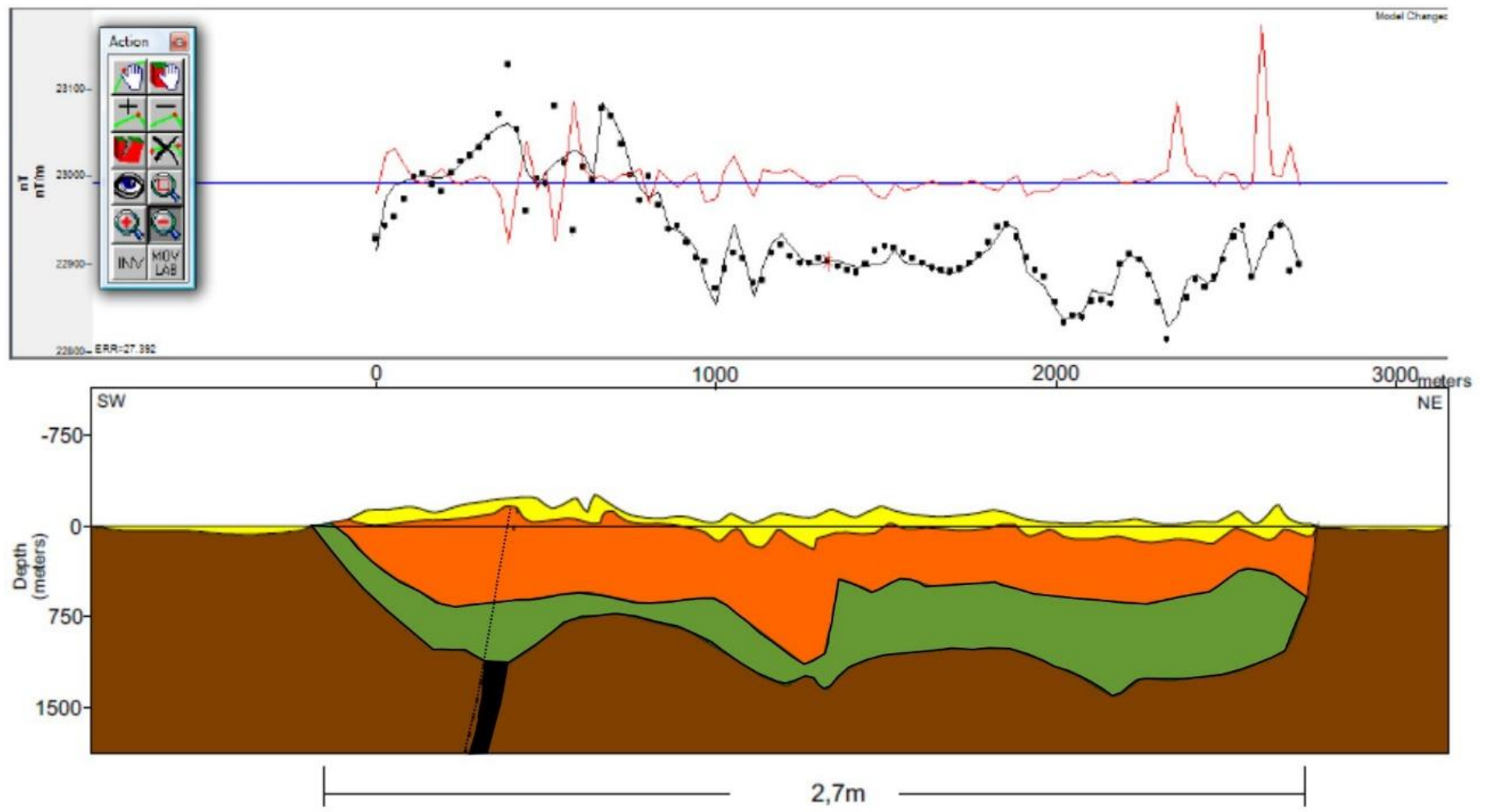

Figure 11 - Geological modeling of the EF profile produced with Geosoft GMSys program.

The sediment packages identified with the GPR records, have similar characteristics to that described by Borges and Nittrouer $(2015,2016)$, in Sepetiba Bay, suggesting a similar origin and a continuity from current marine to continental settings. They should represent sedimentary processes during different sea-level stages. Whereas the top unit, composed largely of fine-grained sediments, may represents a transgressive and high-stand condition with associated marine sedimentation. The sandy bottom unit may represent a lower sea-level stage, characterized by terrestrial sedimentation. That authors obtained by radiocarbon data from a sample collected just below the discontinuity surface, of $6890 \pm 40 \mathrm{yr}$ B.P. This age provides time control for the upper unit composed by fine grained sediments. Assuming that the top of the sandy strata in the study area is correlated with this stratigraphic boundary, it is possible to deduce that the coarse-grained sediments found in the study area were accumulated before the Holocene maximum sea level and the fine-grained strata to sediments related to the MidHolocene maximum transgression at about 5,000 years. Tentatively, using the data obtained in this work the maximum flooding area was mapped according to previous considerations (Fig. 12). Maio (1985) and Pereira at al. (2012) noticed the presence several beach ridges 5-7 $\mathrm{m}$ high, at Sepetiba coastal plain, which are evidence of the maximum sea-level high in the Holocene transgression of Sepetiba region. Alves Martins et al. (2020), also found a sediment package deposited between $\approx 4.5-3.5 \mathrm{kyr}$ BP, where the foraminiferal abundance and assemblages composition, indicate that the study site located near the Santa Cruz Thermoelectric Power Plant was a shallow marine environment, due to the Mid-Holocene relative sea-level highstands.

In addition to these features, in the basement of the EF profiles, the modeling showed the presence of magnetic anomalies probably represented by volcanic rocks, intruded in the granitic basement rocks (Heilbron and Machado, 2003). The presence of these mafic dykes may indicate that the erosion of basement rocks occurred in heterogeneous or fragile area. The values of the magnetic curve errors are associated with factors considered in the modeling, among them, the presence of remnant magnetization, the presence of spikes around the acquisition area and the presence of volcanic rocks above the sedimentary section.

\section{Conclusion}

The integration of geological survey and geophysical data obtained by GPR allowed to interpret and delimit subsurface layers of Sepetiba Bay Basin. In all the analyzed sections the most superficial layers of the radargrams (up to about 8 meters and with $100 \mathrm{MHz}$ antenna) showed sedimentation with clay and silty material, indicating to be associated with a depositional calm environment probably related to the 
Mid-Holocene relative sea-level rise. In contrast, the profounder layers, deeper than 8 meters, presented characteristics of a more energetic sedimentation environment. These sedimentary packages should be related to changes in sea-level rise.
The results of this work also evidence the presence of mafic dykes intruded in granite basement rocks, which indicate the influence of tectonic processes on the basement rocks which should have contributed to model the basin geometry.

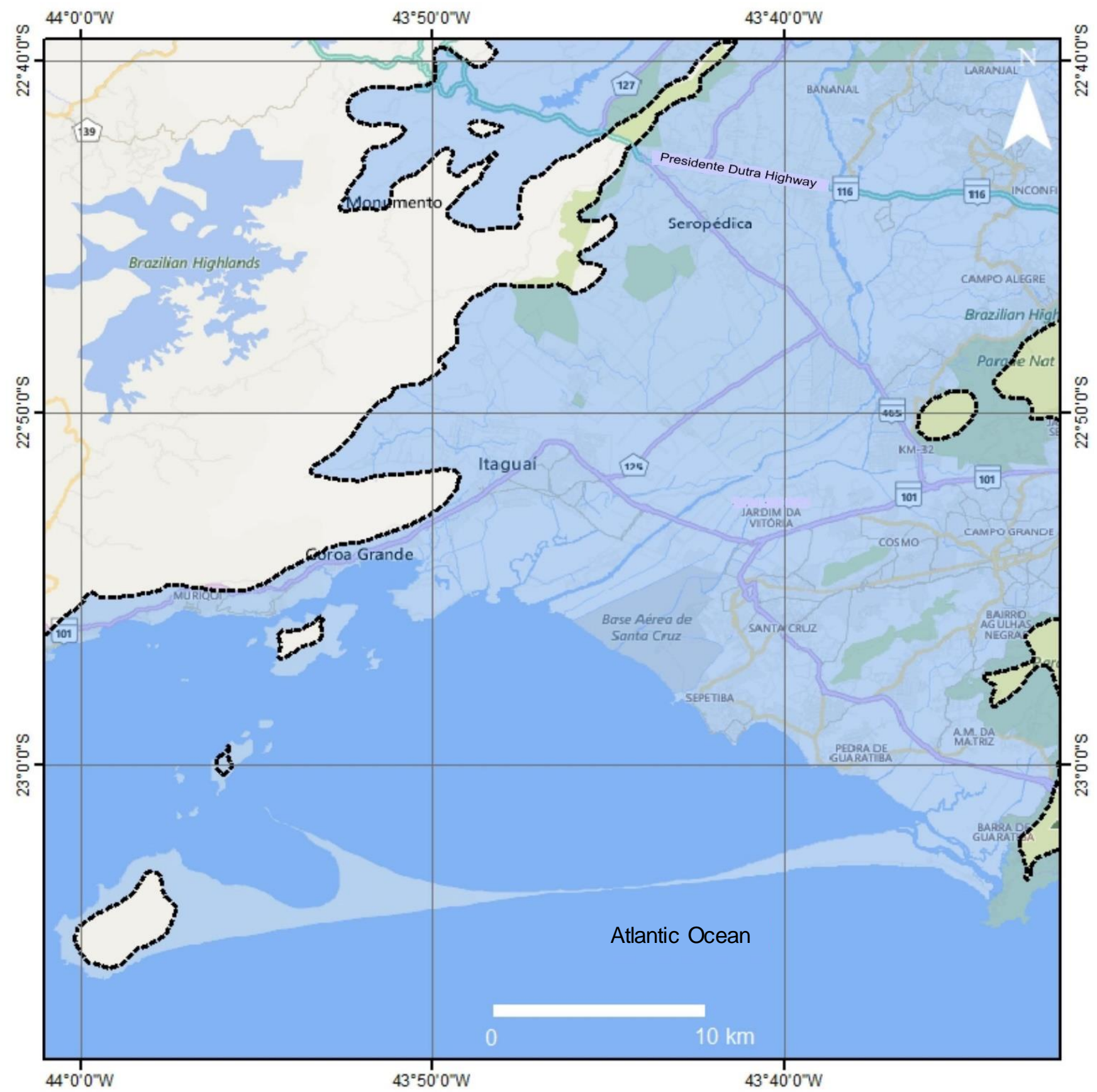

Fig. 12. Geological map of Itaguai area showing Sepetiba Bay. Oceanic transgression limit is presented in blue color, covering large area including the sediments here studied.

\section{Acknowledgment}

The authors would like to thank very Fundação de Amparo à Pesquisa do Estado do Rio de Janeiro - FAPERJ and Conselho Nacional de Desenvolvimento Científico e
Tecnológico - CNPq for the financial support. Virginia Martins and Mauro Geraldes would like to thank the CnPQ for the research grants (process \# 301588/2016-3 and process \# 301470/2016-2, respectively) 


\section{References}

Aagaard, T., Sørensen, P., 2012. Coastal profile response to sea level rise: a process-based approach. Earth Surface Processes and Landforms 37, 354-362. https://doi.org/10.1002/esp.2271

Almeida F.F.M, Hasui Y., Brito Neves B.B., Fuck R.A. 1981. Brazilian structural provinces: an introduction. Ear. Sci. Rev., 17, 1-29.

Alves Martins, M.V., Souza Pinto, A.F., Borghi, L., Carelli, T.G., Morlote, M., Rey, D., Pereira, E., Ramalho, J.C.M., Rocha, F., Geraldes, M., Potratz, G.L., Duleba, W., Reis, T., Guerra, J.V., Rodrigues, M.A.C., 2020. Influence of the Holocene relative sea level in the coastal plain of Sepetiba Bay (Southeast Brazil). Journal of Sedimentary Environments, 5 (1), in press.

Angulo, R.J., Giannini, P.C.F., Souza, M.C., \& Lessa, G.C., 2016. Holocene paleo-sea level changes along the coast of Rio de Janeiro, southern Brazil: Comment on Castro et al. (2014). Anais da Academia Brasileira de Ciências, 88 (4), 2105-2011. https://doi.org/10.1590/0001-3765201620140641

Angulo, R.J., Lessa, G.C. 1997. The Brazilian sea level curves: a critical review with emphasis on the curves from Paranaguá and Cananéia regions. Marine Geology, 140, p. 141-166.

Angulo, R.J., Lessa, G.C., Martin, F.G. et al 2006. A critical review of mid to late Holocene sea-levelfluctuation on the eastern Brazilian coastline. Quaternary Science Reviews 25, 486-506. https://doi.org/10.1016/j.quascirev.2005.03.008

Angulo, R.J., Souza, M.C, Assine, M.L., Pessenda, L.C.R., \& Disaró, S.T., 2008. Chronostratigraphy and radiocarbon age inversion in the Holocene regressive barrier of Paraná, southern Brazil. Marine Geology, 252, 111-119. https://doi.org/10.1016/j.margeo.2008.03.006

barred beach (Sète, France). J. Mar. Syst. 38, 19-34.

Barusseau, J.P., Akouango, E., Bâ,M., Descamps, C., Golf, A., 1996. Evidence for short term retreat of the barrier shorelines. Quat. Sci. Rev. 15, 763-771.

Bird, E. 1987. Physiographic indications of a sea level rise. A discussion paper. Departament of Geography, University of Melbourne, Australia. 14pp.

Bittencourt, A.C.S.P. Dominguez, J.M.L., Medeiros, K.O.P., Guimarães, J.K., Dutra, F.R.L.S., 1979. Quaternary marine formations of the coast of the state of Bahia (Brazil). I : Suguio, K. et al. (eds.), Proceedings of the "1978 International Symposium on Coastal Evolution in the Quaternary", São Paulo (SP), 232- 253.

Bittencourt, A.C.S.P. Leão, Z. M. A. N., Kikuchi, R. K., Dominguez, J. M. L. 1982 Dados preliminares sobre a evolução de delta do rio São Francisco (SE \AL) durante o Quaternário: influência das variações do nível do mar. In: Suguio, K. et al. (eds.), Atas do IV Simpósio do Quaternário no Brasil, rio de Janeiro (RJ): 49-68.

Borges, H.V., \& Nittrouer, C.A. (2015). The paleo-environmental setting of Sepetiba Bay, Rio de Janeiro, Brazil, in the Late Pleistocene: interpretations from high-resolution seismic stratigraphy. Revista Brasileira de Geofísica, 33(4), 565-578. http://dx.doi.org/10.22564/rbgf.v33i4.762

Borges, H.V., \& Nittrouer, C.A. (2016). Sediment accumulation in Sepetiba Bay (Brazil) during the Holocene: A reflex of the human influence. Journal of Sedimentary Environments, 1, 96112. https://doi.org/10.12957/jse.2016.21868
RESEARCH PAPER

Bruun, P., 1962. Sea level rise as a cause of shoreline erosion. Journal of Waterways and Harbor 88, 117-130.

Certain, R., Meulé, S., Rey, V., Pinazo, C., 2005a. Wave transformation on a microtidal barred beach (Sète, France). J. Mar. Syst. 58 (1-2), 19-34.

Cooper, J.A.G., Meirelesc, R.P., Green, A.N., Klein, A.H.F., \& Toldo, E.E. (2018). Late Quaternary stratigraphic evolution of the inner continental shelf in response to sea-level change, Santa Catarina, Brazil. Marine Geology, 397, 1-14.

Cunha, B.C.A., Rocha, D., Geraldes, M.C., Pereira, S.D., Almeida, A. C. 2009. Pb isotopic signatures in sediments of a subtropical coastal lagoon: Anthropogenic sources for metal contamination in the Sepetiba Bay (SE-Brazil). Journal of Coastal Research. [S. 1.], v.56, p. $797-801$.

Cunha, Bruno and Machado, Wilson and Souza, Ariadne and Araújo, Daniel and Garnier, Jérémie and Martins, Alan and Saliba, Bruno and Geraldes, Mauro. (2018). Lead source assessment by isotopic and elementary composition in the transition from pristine and polluted conditions of coastal sediments. Journal of Sedimentary Environments 3, 46-53. https://doi.org/10.12957/jse.2018.33890.

Dantas, M., 2000. Geomorfologia do Estado do Rio de Janeiro. Ministério De Minas e Energia, Secretaria de Minas E Metalurgia, CPRM - Serviço Geológico do Brasil, BRASÍLIA. D10.13140/RG.2.2.32582.57923

Dobrin, M.B. and C.H. Savit, (1988). Introduction to Geophysical Prospecting. 4th Edition McGraw Hill Book Co., New York.

Dominguez, J.M.L. 1982. Evolução quaternária da planície costeira associada à foz do rio Jequitinhonha (BA): influência das variações do nível do mar e da deriva litorânea de sedimentos. M.S.D. Thesis, Universidade Federal da Bahia, Salvador, 79p

Dominguez, J.M.L., Bittencourt, A. C. S. P., Martin, L., Silva, I. R., Medeiros, C.O., 1982. Evolução paleográfica do delta do rio Jequitinhonha durante o Quaternário: Influência das variações do nível do mar. In: Suguio, K. et al. (eds.), Atas do IV Simpósio do Quaternário no Brasil, Rio de Janeiro (RJ), 69-92.

Dominguez, J.M.L., Silva, S.B.M., Souza Filho, J.R. et al 1981. Esquema evolutivo da sedimentação quaternária nas feições deltaicas dos rios São Francisco (SE \AL), Jequitinhonha (BA), Doce e Paraíba do Sul (RJ). Rev. Bras. Geoc., 11 (4), 227-237.

Ferrari, A.L. 2001. Evolução Tectônica do Gráben da Guanabara. PhD Thesis, Universidade de São Paulo, São Paulo, 412p.

Ferrari, A.L., 1990. A geologia do "rift" da Guanabara (RJ) na sua porção centro-ocidental e sua relação com o embasamento préCambriano. In: SBG, Congresso Brasileiro de Geologia, 36. Anais, volume 6: 2858-2872.

Flexor, J.M., Martin, L. 1979. Utilisation Du rapport isotopique ${ }^{13} \mathrm{C} /{ }^{12} \mathrm{C}$ come indicateur d'oscillations lagunares. In: Suguio, $\mathrm{K}$. et al. (eds.), Proceedings of the "1978International Symposium of Coastal Evolution in the Quaternary", São Paulo (SP) 356375.

Gallagher, K. Brown, R., 1999. The Mesozoic denudation history of the Atlantic margins of southern Africa and southeast Brazil and the relationship to offshore sedimentation. Geological Society, London, Special Publications. Geological Society, London, Special Publications. 153: 41-53. https://doi.org/10.1144/GSL.SP.1999.153.01.03.

Geraldes, M.C., Paula, A.H., Godoy, J.M., Valeriano, C.M., 2006. $\mathrm{Pb}$ isotope signatures of sediments from Guanabara Bay, SE 
Brazil: evidence for multiple anthropogenic sources. Journal Geochemical Exploration [S. 1.], 88 (1-3), 384-388.

Harari, J., Camargo, R. 1993. Tides and mean sea level in Recife (PE) $-8^{\circ} 33^{\prime} \mathrm{S} 34^{\circ} 51.9^{\prime} \mathrm{W}-1946$ to 1988 . Boletim do Instituto Oceanografico, Universidade de São Paulo.

Heilbron, M., Machado, N. 2003. Timing of terrane accretion in the Neoproterozoic-Eopaleozoic Ribeira Orogen (SE Brazil). Precambrian Research 125(1-2):87-112. DOI: 10.1016/S03019268(03)00082-2

Hein C.J., Fitzgerald D.M., Menezes, J.T., Cleary, W.J., Klein A.H.F., \& Albernaz M.B. (2014). Coastal response to late-stage transgression and sea-level highstand. GSA Bulletin, 126 (3/4) 459-480. https://doi.org/10.1130/B30836.1

Hein, C.J., FitzGerald, D.M., Menezes, J.T., Cleary, W.J., Klein, A. H.F., Albernaz, M.B., 2014. Coastal response to late-stage transgression and sea-level highstand. GSA Bulletin, 126 (3-4): 459-480. https://doi.org/10.1130/B30836.1

Jesus, P.B., Dias, F.F., Muniz, R.A., Macário, K.C.D., Seoane, C.S., Quattrociocchi, D.G.S., Cassab, R.C.T., Aguilera, O., Souza, R.C.C.L., Alves, E.Q., Chanca, I.S., Carvalho, C.R.A., \& Araujo, J.C. (2017). Holocene paleo-sea level in southeastern Brazil: an approach based on vermetids shells. Journal of Sedimentary Environments, 2, 35-48. https://doi.org/10.12957/jse.2017.28158

Khan, N.S., Ashe, E., Shaw, T.A., Vacchi, M., Walker, J., Peltier, W.R., Kopp, R.E., Horton, B.P., 2015. Holocene Relative SeaLevel Changes from Near-, Intermediate-, and Far-Field Locations. Current Climate Change Reports 1 (4) ,pp.247-262. https://doi.org/10.1007/s40641-015-0029-z

Kominz, M. A., 2001. Sea Level variations over geologic time. Academic Press. Academic Press, San Diego, pp. 2605-2613. https://doi.org/10.1006/rwos.2001.0255

Martin, L., Suguio, K., 1992. Variations of coastal dynamics during the last 7000 years recorded in the beach-ridge plains associated with river mouths: example from the central Brazilian coast. Palaeogeogr. Palaeoclim. Palaeoecol., 99, 119140.

Martin, L., Flexor, J.M., Vilasboas, G.S., Bittencourt, A.C.S.P., Guimarães, M.M.M. (1979a). Courbe de variation du niveau relatif de la mer au cours des 7.000 derniëres annëes sur un secteur homonëne du littoral brésilien (nord de Salvador Bahia). In: Suguio, K. et al. (eds.), Proceedings of the "1978 International Symposium on Coastal Evolution in the Quaternary", São Paulo, 264 - 274.

Mizusaki, A.M.P., Thomaz-Filho, A., Milani, E.J., De Césero, P., 2002. Mesozoic and Cenozoic igneous activity and its tectonic control in northeastern Brazil". Journal of South American Earth Sciences. $15 \quad$ (2), 183-198. https://doi.org/10.1016/S0895-9811(02)00014-7

Monroe, J. S., Wicander, R., 2005. Physical Geology: Exploring the Earth. Fifth edition; Thomson Brooks/Cole, p. 162.

Muehe, D. 1994. Gemorfologia Costeira. In: Guerra, A.J.T. and Cunha, S.B. (orgs.). Geomorfologia: uma atualização de bases e conceitos. Editora Bertand Brasil. Capitulo 6. 253-308.

Murray-Wallace, C.V., Woodroffe, C.D., 2014. Sea-level changes: the emergence of a Quaternary perspective. Publisher:
RESEARCH PAPER

Cambridge University Press, pp. 1-40 https://doi.org/10.1017/CBO9781139024440.002

Paula, A. H., Geraldes, M. C. 2005. Holocene Pb isotope evolution: the record of the anthropogenic activity in the last 6,000 years. TERRÆ 2(1-2), 55-60.

Pinto, A.F.S., Martins, M.V.A., Rodrigues, M.A.C., Nogueira, L., Laut, L.L.M., Pereira, E., 2016. Late Holocene evolution of the Northeast intertidal region of Sepetiba Bay, Rio de Janeiro (Brazil). Journal of Sedimentary Environments, 1(1), 107-138. htps://doi.org/10.12957/jse.2016.21924

Pinto, A.F.S., Ramalho, J.C.M., Borghi, L., Carelli, T.G., Plantz, J.B., Pereira, E., Terroso, D., Santos, W.H., Geraldes, M.C., Rocha, F., Rodrigues, M.A.C., Laut, L., Martins, M.V.A., 2019. Background concentrations of chemical elements in Sepetiba Bay (SE Brazil). Journal of Sedimentary Environments, 4 (1), 108-123. https://doi.org/10.12957/jse.2019.40992

Pirazolli, P.A. 1986. Secular trends of relative sea-level changes indicated by tide-gauge records. Journal of Coastal Research SI 1, 1-26.

Potratz, G.L., Geraldes, M.C., Bizzi, S., Nogueira, L., Martins, M.V.A., 2019. Using lead isotopes and potentially toxic elements to trace pollutant sources in the northern region of Guanabara Bay, southeastern Brazil. Marine Pollution Bulletin, 144, 216-223.

Rocha, D. S., Cunha, B. C. A., Geraldes, M.C., Pereira, S.D., Almeida, A.C., 2010. Metais pesados em sedimentos da baía de Sepetiba, RJ: implicações sobre fontes e dinâmica da distribuição pelas correntes de maré. Geochimica Brasiliensis $24,63-70$.

Roncarati, H., Barrocas, S.L.S., 1978. Projeto Sepetiba: Estudo geológico preliminar dos sedimentos recentes superficiais da Baía de Sepetiba, Município do Rio de Janeiro, Itaguaí e Mangaratiba, RJ. Rio de Janeiro: CENPES-Petrobras (Relatório preliminar).

Suguio, K., 2003.Tópicos de geociências para o desenvolvimento sustentável: as regiões litorâneas. Revista do Instituto de Geociências - USP (Série Didática), 40 p.

Suguio, K., Martin, L, Bittencourt, A.C.S.P., Dominguez, J.M.L., Flexor, J.M., Azevedo, A.E.G. 1985. Flutuação do nível do mar durante o Quaternário superior ao longo do litoral brasileiro e suas implicações na sedimentação costeira. Revista Brasileira de Geociências, 15, 273-286.

Suguio, K., Martin, L., 1978. Formações quaternárias marinhas do litoral paulista e sul fl uminense (Quaternary marine formations of the State of São Paulo and southern Rio de Janeiro). In: International Symposium on Coastal Evolution in the Quaternary, 1978, São Paulo. Anais. São Paulo: Special Publication, $n^{\circ} 1$, p. 1-55.

Suguio, K., Martin, L., 1982. Significance of Quaternary sea-level fluctuations for delta construction along the Brazilian coast. Geo-Marine Letters, 1 (3/4), 181-185.

Wong, P.P., I.J. Losada, J.-P . Gattuso, J. Hinkel, A. Khattabi, K.L. McInnes, Y. Saito, and A. Sallenger , 2014: Coastal systems and low-lying areas. In: Climate Change 2014: Impacts, Adaptation, and Vulnerability. Part A: Global and Sectoral Aspects. Contribution of Working Group II to the Fifth Assessment Report of the Intergovernmental Panel on Climate Change [Field, C.B., V.R. Barros, D.J. Dokken, K.J. Mach, M.D. Mastrandrea, T.E. Bilir, M. Chatterjee, K.L. Ebi, Y.O. Estrada, 
R.C. Genova, B. Girma, E.S. Kissel, A.N. Levy, S. MacCracken, P.R. Mastrandrea, and L.L. White (eds.)]. Cambridge University Press, Cambridge, United Kingdom and New York, NY, USA, pp. 361-409.
Zalán, P.V., Oliveira, J.A.B., 2005. Origem e evolução estrutural do Sistema de Riftes Cenozóicos do Sudeste do Brasil. B. Geoci. Petrobras, Rio de Janeiro, 13 (2), 269-300.

\section{Appendix 1}

Profile AB1 - 100 Mhz
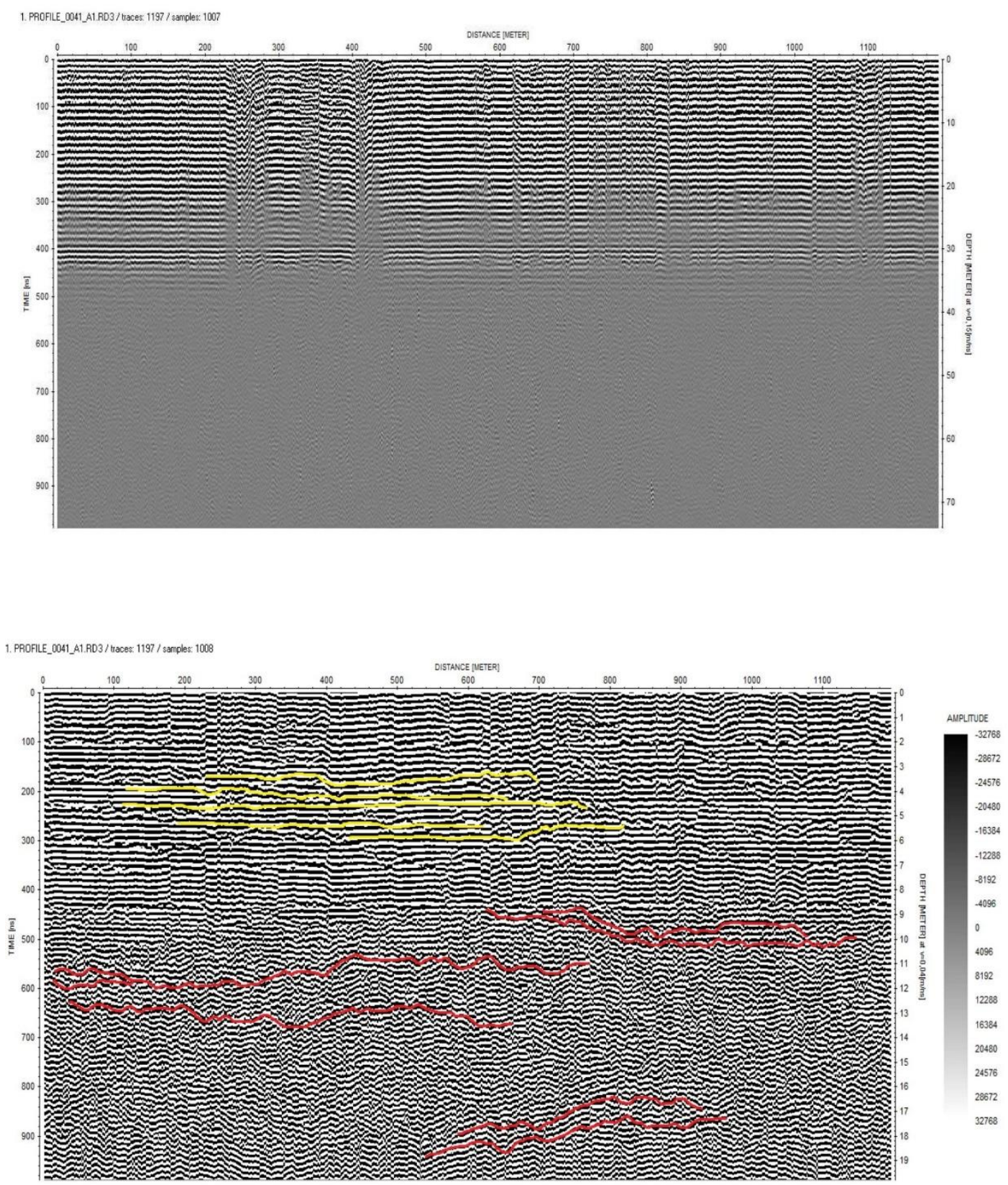

SM-Fig. 1. (A) Radargram of the AB1 profile before processing. (B) Radargram of the interpreted AB1 profile. Yellow lines (flat-parallel lamination) and red lines (wavy to chaotic stratifications). 
Profile AB2 - 100 Mhz
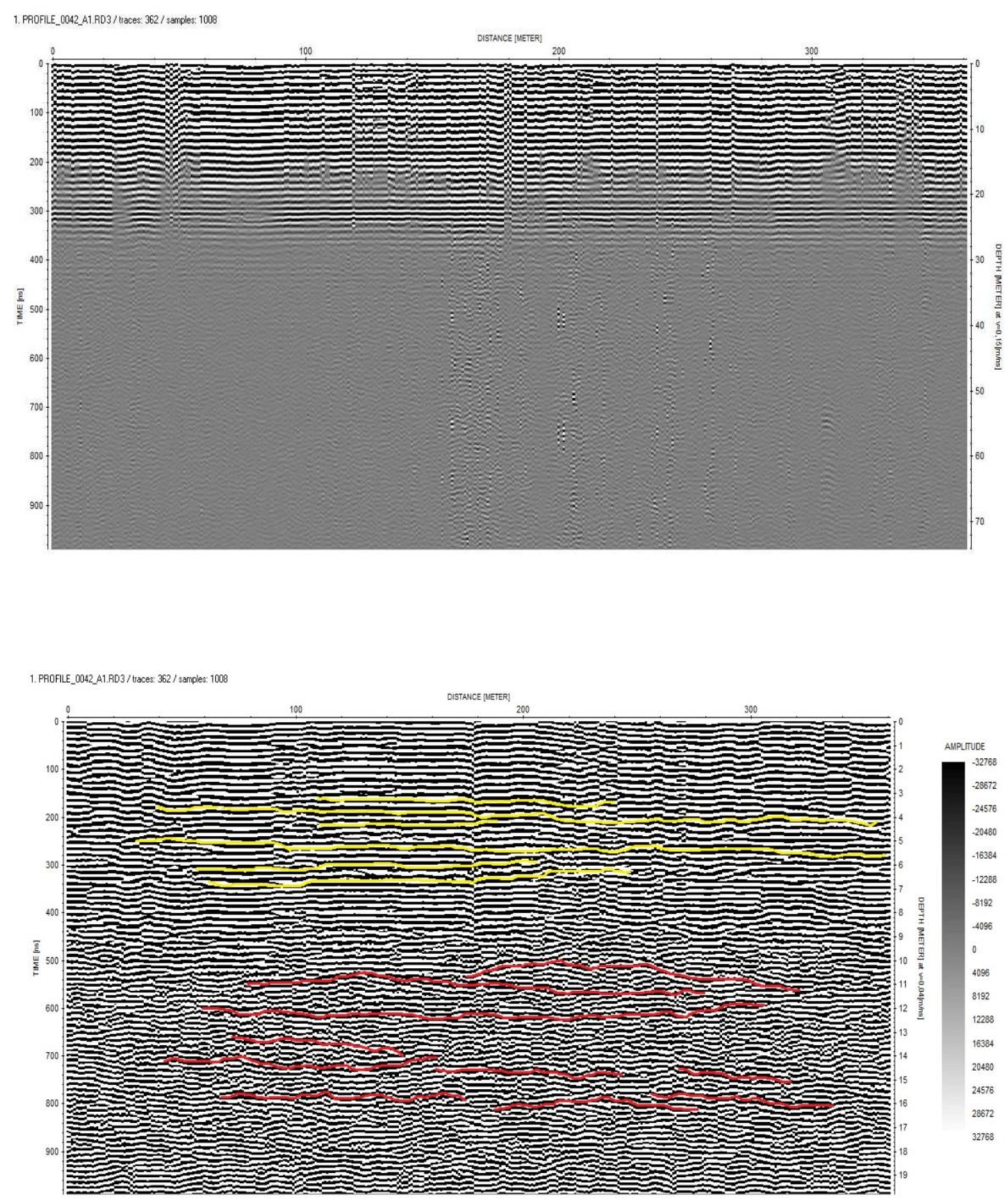

SM-Fig. 2. (A) Radargram of AB2 profile before processing. (B) Radargram of the interpreted AB2 profile. Yellow lines (flat-parallel lamination) and red lines (wavy to chaotic stratifications). 

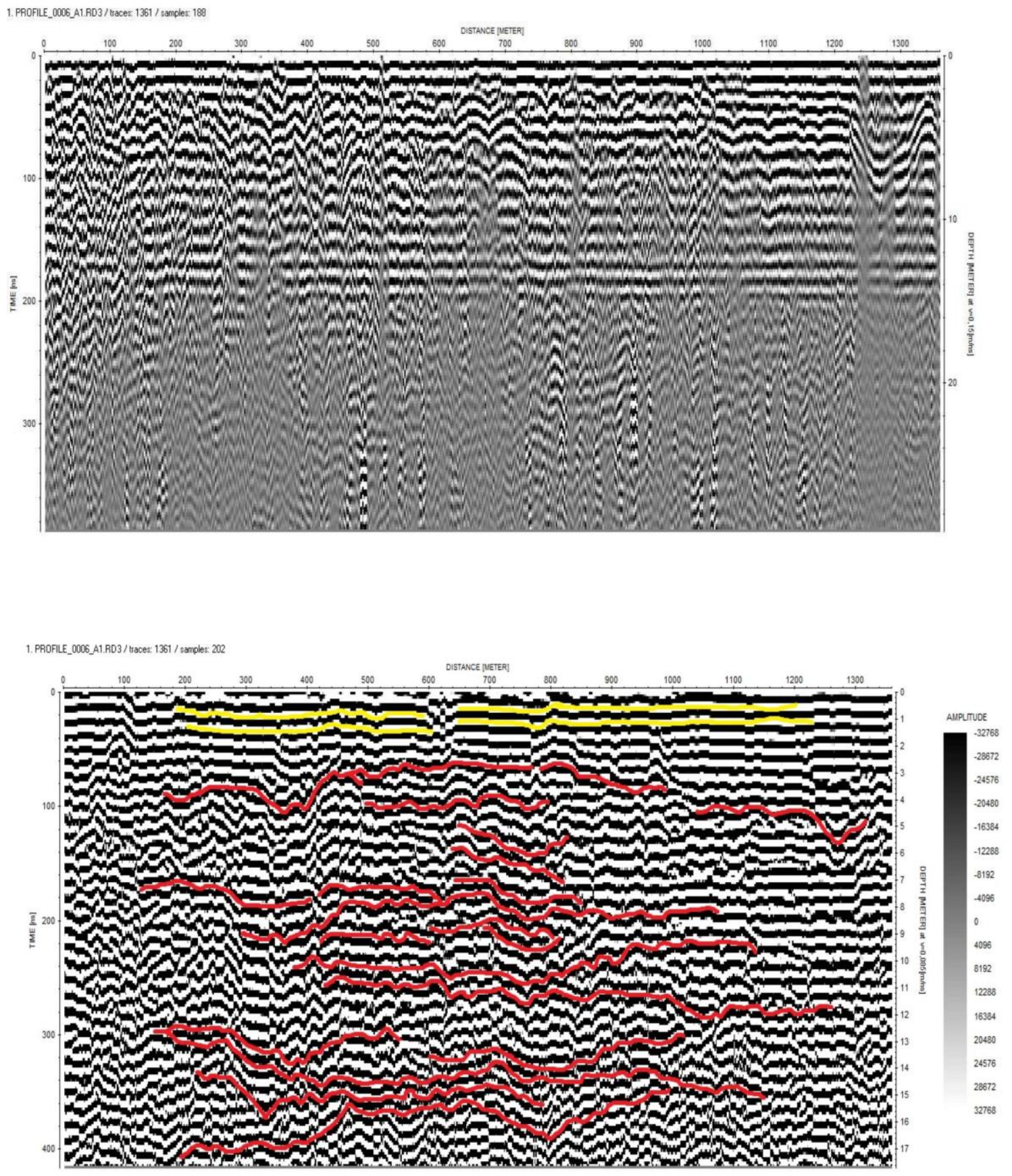

SM-Fig. 3. (A) Radar of Base $50 \mathrm{MHz}$ profile before processing. (B) Radargram of the Base 50 profile interpreted. Yellow lines (flatparallel lamination) and red lines (wavy to chaotic stratifications). 
Journal of Sedimentary Environments

Published by Universidade do Estado do Rio de Janeiro

4 (4): 518-539. October-December, 2019

doi: 10.12957 /jse.2019.47382

RESEARCH PAPER

Base Profile - $100 \mathrm{MHz}$.
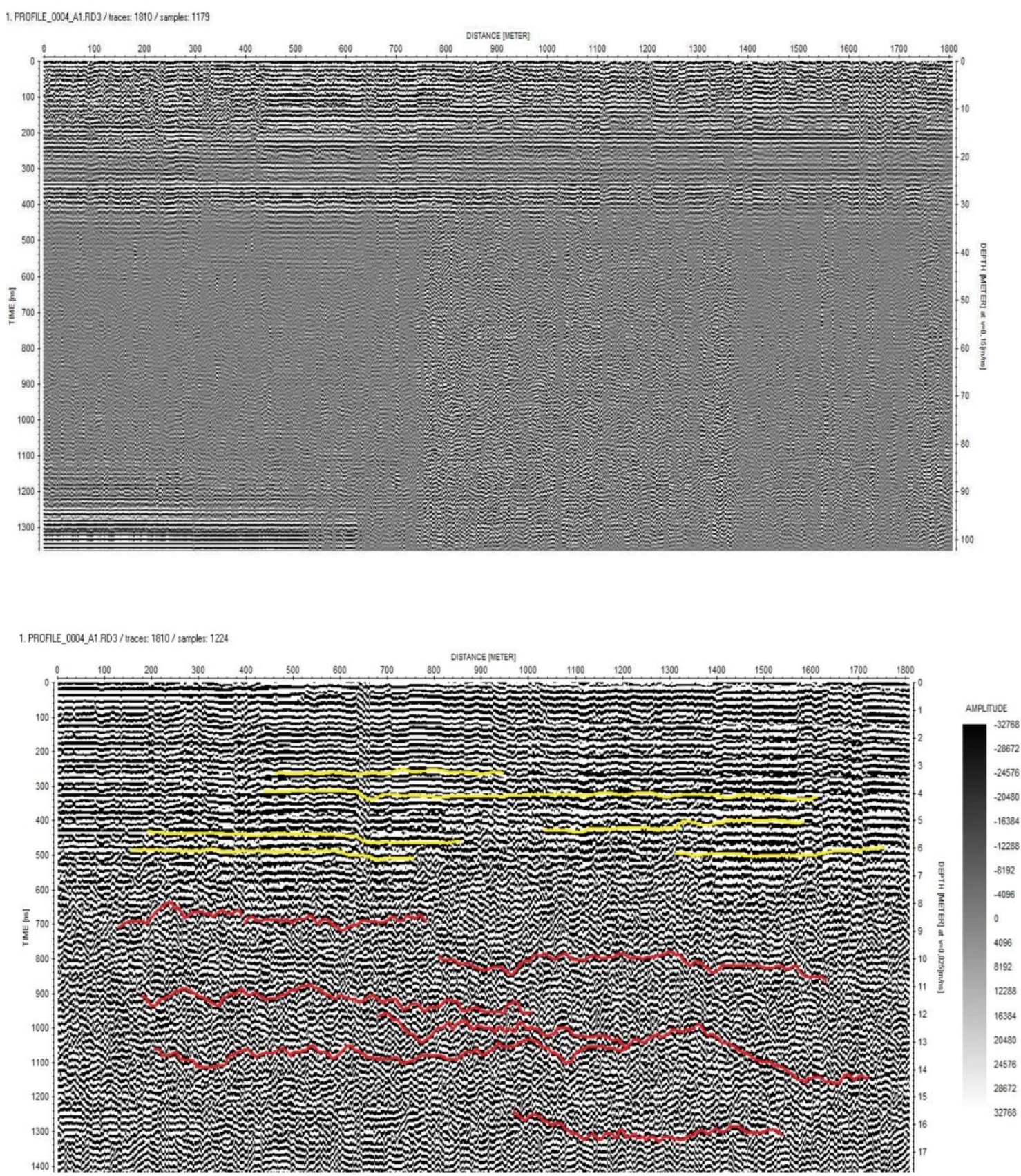

SM-Fig. 4. (A) Radar of the $100 \mathrm{MHz}$. Base Profile before processing. (B) Radargram of the Base 100 profile interpreted. Yellow lines (flat-parallel lamination) and red lines (wavy to chaotic stratifications). 
Journal of Sedimentary Environments

Published by Universidade do Estado do Rio de Janeiro

4 (4): 518-539. October-December, 2019

doi: 10.12957 /jse.2019.47382

RESEARCH PAPER

EF Profile - $100 \mathrm{MHz}$.
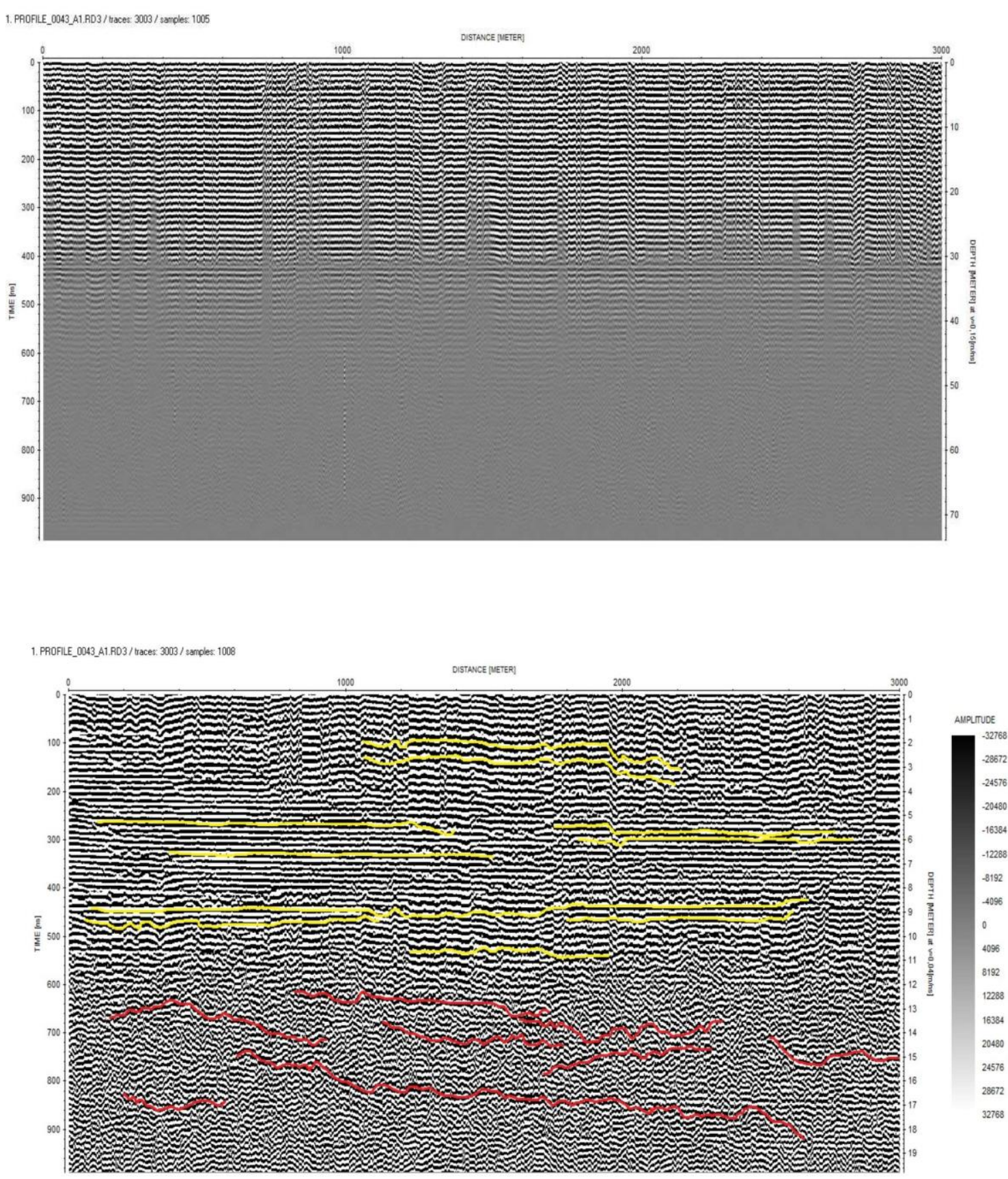

SM-Fig. 5. (A) Radar of the EF $100 \mathrm{MHz}$ profile before processing. (B) Radargram of the interpreted EF 100 profile. Yellow lines (flatparallel lamination) and red lines (wavy to chaotic stratifications).

Farm Profile - $50 \mathrm{MHz}$. 

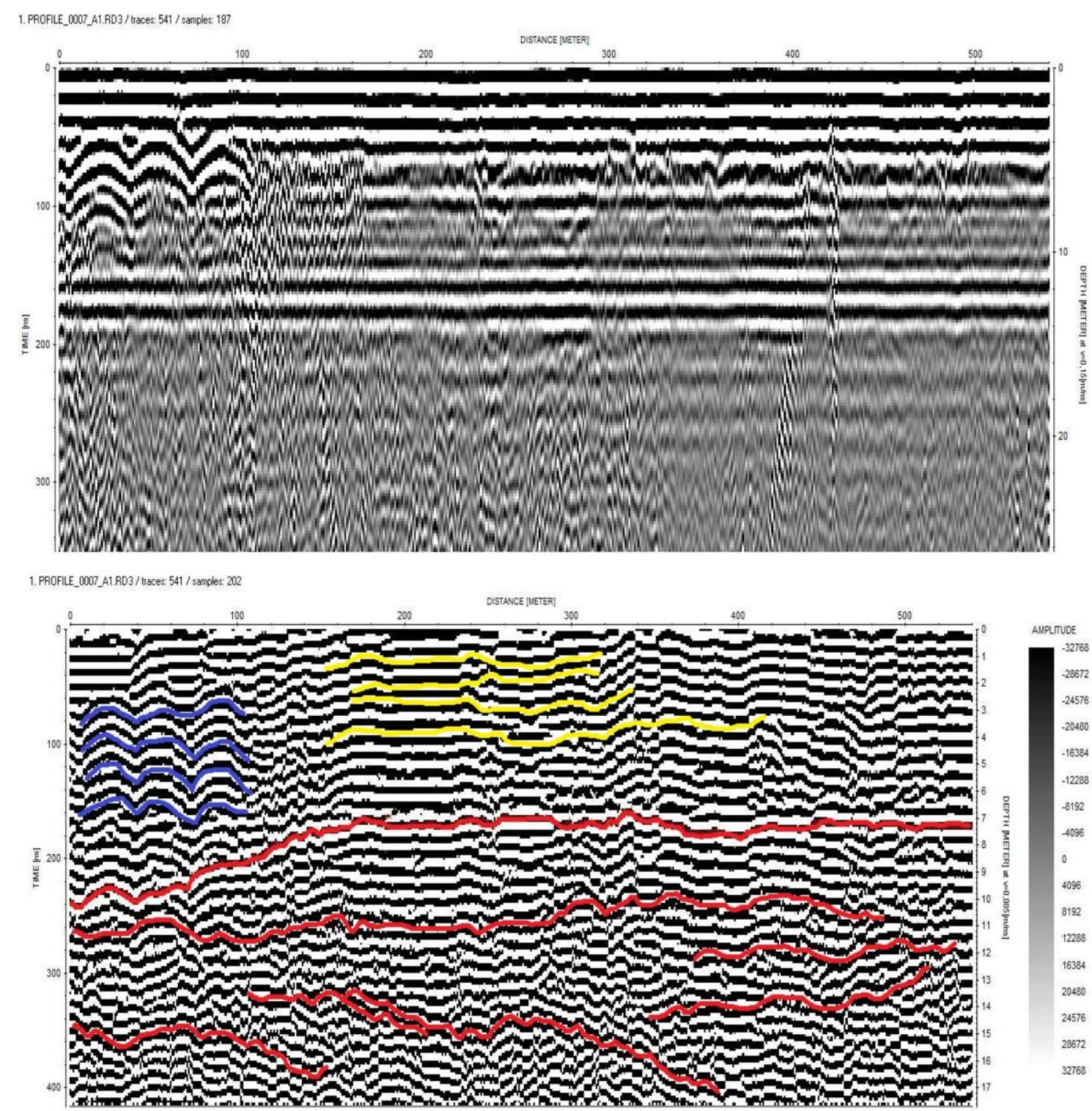

SM-Fig. 6. (A) Farm Profile Radar $50 \mathrm{MHz}$. before processing. (B) Radargram of the profile Farm 50 interpreted. Yellow lines (flatparallel lamination), red lines (wavy to chaotic stratifications) and blue lines show likely buried tubes. 